\title{
"TRACHY-PHONOLITE LAVA PEBBLES USED IN THE ANCIENT SETTLEMENT OF OPLONTIS (TORRE ANNUNZIATA, NAPLES): PETROCHEMICAL DATA SUPPORTING THE ORIGIN FROM AN OLD EFFUSIVE ACTIVITY OF THE SOMMA-VESUVIUS VOLCANO,
}

\author{
Alberto Renzulli ${ }^{*}, 1$, Patrizia Santi ${ }^{1}$, Giuseppina Balassone ${ }^{2}$, Giovanni di Maio ${ }^{3}$, \\ Alberto De Bonis ${ }^{2}$, Valentino Di Donato ${ }^{2}$, Vincenzo Morra ${ }^{2}$ \\ (1) Dipartimento di Scienze Pure e Applicate, Campus Scientifico “Enrico Mattei”, Università degli Studi di Urbino Carlo Bo, \\ Urbino, Italia \\ (2) Dipartimento di Scienze della Terra, dell'Ambiente e delle Risorse, Università di Napoli Federico II, Napoli, Italia \\ (3) Geomed s.r.l. "Geoarcheologia e Geologia Ambientale”, Scafati, Italia
}

Article history

Receveid February 27, 2018; accepted September 24, 2018.

Subject classification:

Lava pebbles; Trachy-phonolites; Archaeometry; Oplontis; Somma-Vesuvius.

\begin{abstract}
In the southern and south-eastern sectors of Somma-Vesuvius volcano (Campania region, southern Italy), archaeological sites covered by the deposits of A.D. 79 Vesuvius eruption, and dating back to Protohistoric and Roman periods are characterized by the presence of numerous lava pebbles used in the human settlements. In this work we present the new case study of the lava samples found with other materials used in building foundations of the Roman site of Oplontis (the "Villa of Poppea" or "Villa A" or Oplontis A; and the ancient commercial structure of Oplontis B). This new data set of lava pebbles of different lithologies was also compared with that of the archaeological site of Longola, in order to unravel the source provenance from distinct evolutionary phase of the Somma-Vesuvius volcano. According to major and trace elements composition, lava pebbles are all compatible with the Somma-Vesuvius magmas erupted before $8 \mathrm{ka} \mathrm{BP}$ and are represented, according to modal mineralogy and whole-rock geochemistry, by two groups belonging to the slightly silica undersaturated series: several basic-intermediate lithotypes (mainly phonolitic tephrites to basaltic trachyandesites) and trachyphonolites. Despite the obvious abundance of volcanic rock pebbles, as the settlements were built on the Somma-Vesuvius volcano, the trachy-phonolite lava pebbles do not match with any lithostratigraphic units mapped in the up-to-now available literature data. Nevertheless, the trachy-phonolite lava pebbles show (i) a comagmatic relationships with the products erupted by Somma-Vesuvius before 8 ka BP as pyroclastic products (i.e. pumices) and (ii) a good petrological affinity with lava trachyte ejecta included within the Plinian eruptions preceding the A.D. 79 event.

The basic-intermediate and the trachy-phonolite lava pebbles from both the sites of Oplontis and Longola, have to be interpreted as an old effusive activity of the Somma-Vesuvius. In order to form lava pebbles, reworking could have taken place either on the original lava flows/autoclastic breccias or on the lithic lava fragments of pyroclastic/breccia deposits produced by the explosive events preceding the A.D. 79 eruption.
\end{abstract}

\section{INTRODUCTION}

Petro-archaeometric studies, recently performed in some archaeological sites located in the surrounding areas of the Somma-Vesuvius volcano (Campania region, southern Italy), were focused on numerous lava pebbles of different compositions used for different purposes in the past human activities [Balassone et al., 2016 and reference therein]. Some examples are represented by blocks employed as lateral supports for palings, weights for fishing and counterweights, stone base in building foundations, millstones, etc. The present case study 
concerns the archaeological site located in the southern sectors of the Somma-Vesuvius stratovolcano, consisting of lava pebbles coming from the famous "Villas" and other structures of Oplontis, i.e. large and sumptuous country houses, as well as commercial/artisanal centers of Roman times built along the ancient coastal cliff of the present-day town of Torre Annunziata, and covered by the deposits of the A.D. 79 Vesuvius eruption. Because of the similarity of the stone findings, we are going to reconsider, within the present work, the data set produced by Balassone et al. [2016] for the Longola settlement, a Protohistoric perifluvial village from the Middle Bronze Age to the sixth century BC, located ca. 10 km northeast of the ancient Pompei (Figure 1).

This is not a canonical archaeometric work to unravel the provenance of volcanic rock artifacts (e.g. millstones, obsidian) found in archaeological sites hundreds of kilometers far from the volcano edifice and use- ful in detecting trade commerce and routes in antiquity [Renzulli et al., 1999, Renzulli et al. 2002a, b; Santi et al. 2004, 2010, 2013, 2015, 2017]. The archaeometric aim of the present study concerning the archaeological sites of Oplontis and Longola, is addressed to some lithologies belonging to the same volcano the settlements were built on (i.e. Somma-Vesuvius), but not directly matching with the stratigraphic succession of the volcano edifice.

Recently Balassone et al. [2016] emphasized that several "trachyte" lava pebbles found at Longola could result from erosional processes of effusive products preceding some of the oldest Plinian eruptions of the Somma-Vesuvius. Witnesses of this effusive activity, which was partly/completely eroded, involved in caldera collapses and/or buried by the activity younger than 8 ka BP, could be also identified in searching and studying lithic clasts within pyroclastic deposits of the vol-

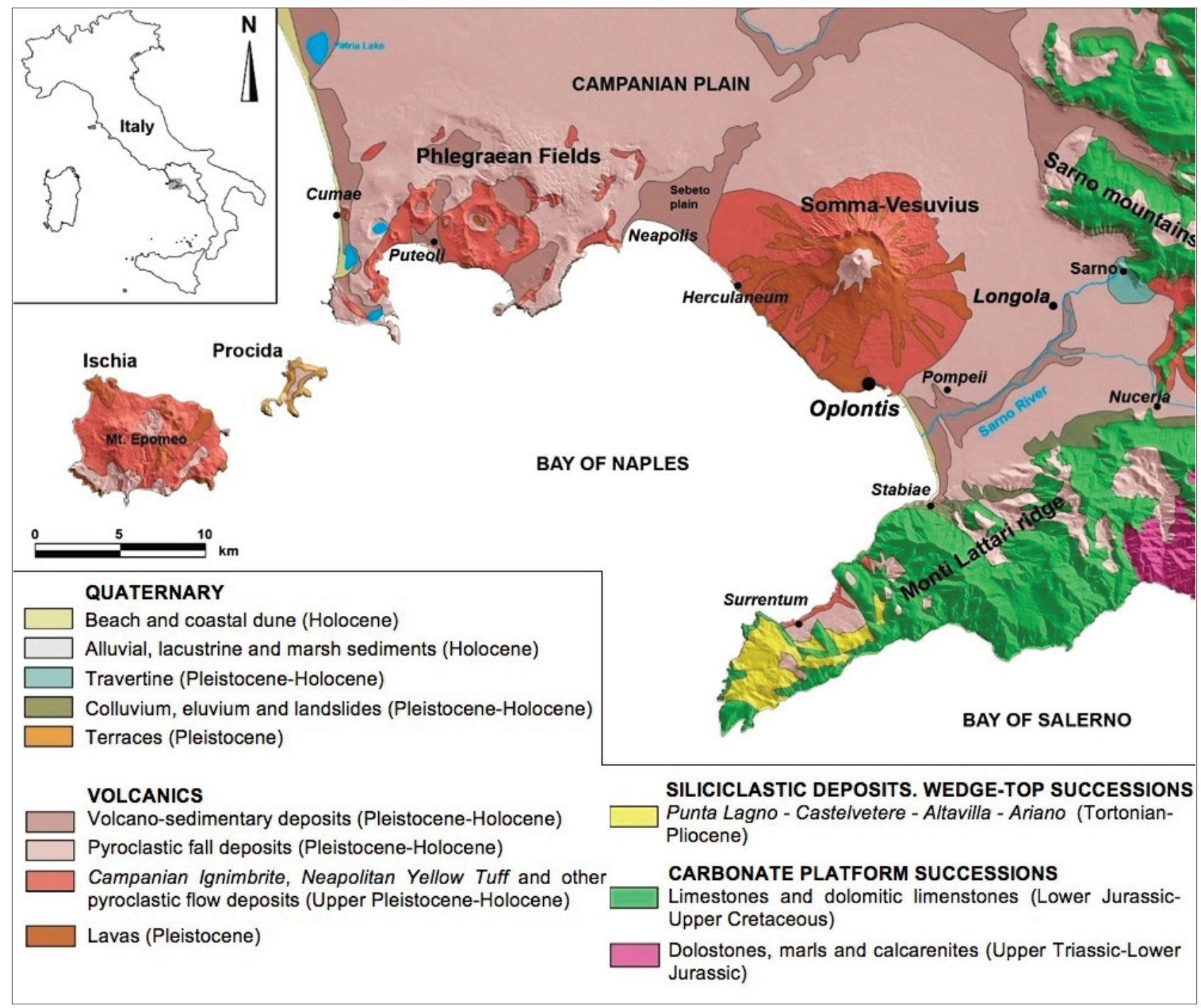

FIGURE 1. Geological sketch map of the Bay of Naples (Campania region, southern Italy), with location of the Oplontis and Longola archaeological sites [modified from De Bonis et al., 2016]. 


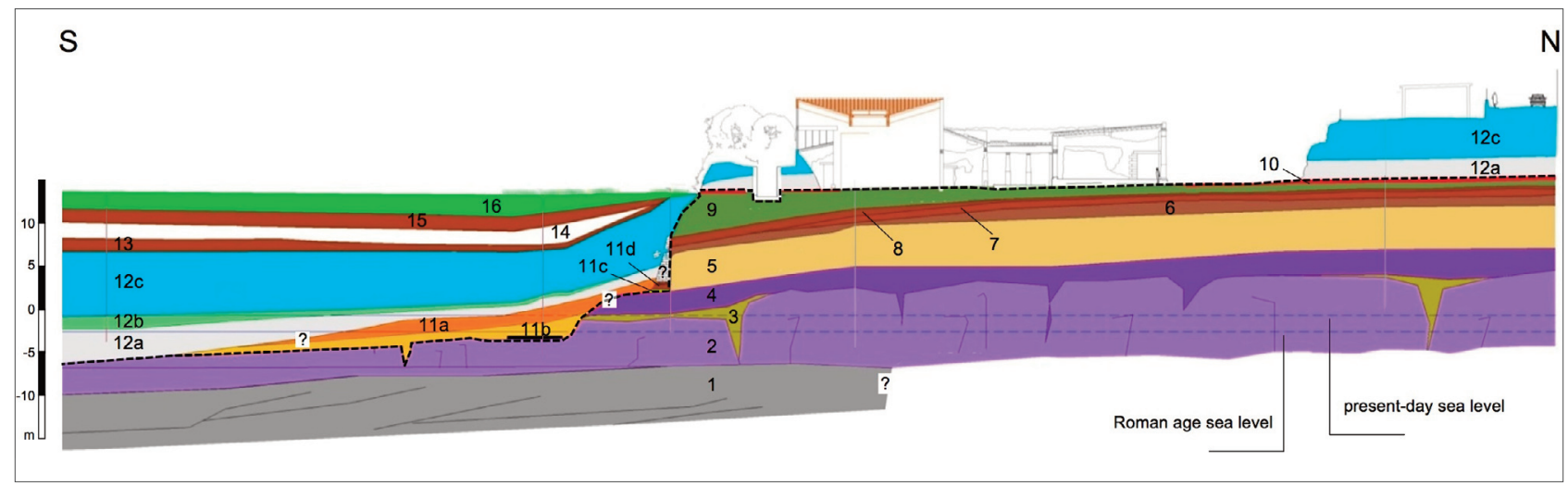

FIGURE 2. Schematic geoarchaeological section of the "Villa A" of Oplontis; pyroclastic deposits numbered from 1 to 10 are preA.D. 79, whereas from 11 to 16 are post-A.D. 79 [see Di Maio, 2014, for further details].

cano, as well as in other archaeological contexts.

In order to verify the lava fragment lithotypes among the stones found in the archaeological excavations in the Vesuvius area, whose lithologies seem to be lacking on the flanks of the volcano, the present study will present petrochemical data on lava pebbles from another important archaeological site in the southern portion of the Vesuvius edifice: villas and other structures of Oplontis (Figure 2). On the basis of modal mineralogy, petrography and major-trace elements geochemistry methodological approach, a comprehensive comparison among the Longola study [Balassone et al., 2016], new Oplontis lava pebbles and available literature data of SommaVesuvius extrusives (also comprising lava ejecta) will be performed in the present study. Comparisons with trachyte lavas belonging to the Phlegraean Fields were also carried out, in order to rule out this area as a possible source for the investigated volcanic pebbles.

\section{THE ARCHAEOLOGICAL BACKGROUND}

When Vesuvius erupted in A.D. 79, private villas and public commercial/artisanal structures were located along the Bay of Naples coastline [Di Maio, 2014; Muntasser and Di Maio, 2014; Izzo et al., 2016]. In particular, the Villas of Oplontis, including the "Villa of Poppea" or "Villa A" and the ancient commercial structure of Oplontis B [Fergola, 2004; Guzzo and Fergola, 2000] belong since the 1997, together with Pompei and Ercolano, to the Unesco World Heritage (Figures 2,3). Nowadays, the archaeological sites of "Villa A" and Oplontis $B$ lie more than 500 meters inland and 5 to 6 meters below the street level of the modern town of Torre Annunziata. Thanks to the geo-archaeological research carried out during the course of the "Oplontis Project"
[Di Maio, 2014], it is now known that "Villa A" was perched on a cliff 14 meters above the ancient shore (Figure 2), while Oplontis B stood much lower, at about 2 meters above the sea-level referred to the roman time. During the stratigraphic analysis, deep core samples were collected at locations close to the archaeological sites, along with core samples from other key spots located between Pompei and Torre Annunziata. Some of the cores were taken up to a depth of 30 meters.

The "Villa A", was firstly discovered in the $16^{\text {th }}$ century A.D. and attributed to the half of $1^{\text {st }}$ century BC (Imperial Age) according to the used techniques of walling and painting [Fergola and Pagano, 1998]; the discovery of restoration signs [Clarke and Muntasser, 2014] should account for the well known earthquake dating back to the A.D. 62. Archaeological excavations of the area started in 1839, but they had actually been working only between 1964 and 1984 [Lucibello et al., 2007]. Currently, 98 spaces and a very big swimming pool of $60 \mathrm{~m}$ were excavated.

The Oplontis B, discovered in 1974, is located at about $300 \mathrm{~m}$ from the "Villa A" [Lucibello et al., 2007; Di Maio, 2014]. This structure was built at the end of the $2^{\text {nd }}$ century BC for commercial use [Malandrino, 1980]. Between 2012 and 2013, during the researches carried out within the "Oplontis Project" [Thomas et al., 2013], 17 rooms distributed in two different levels (stores in the bottom and houses upstairs) were discovered. The A.D. 79 catastrophic eruption of the Vesuvius destroyed and covered with its pyroclastic deposits [Santacroce and Sbrana, 2003 and references therein] the entire area of Oplontis as well as Pompei and Ercolano. Figure 3 shows a representative outcrop of the pebbles horizon found in the Oplontis B site. Lava pebbles investigated in the present work are located below the post A.D. 62 anthropogenic soil, followed upward 

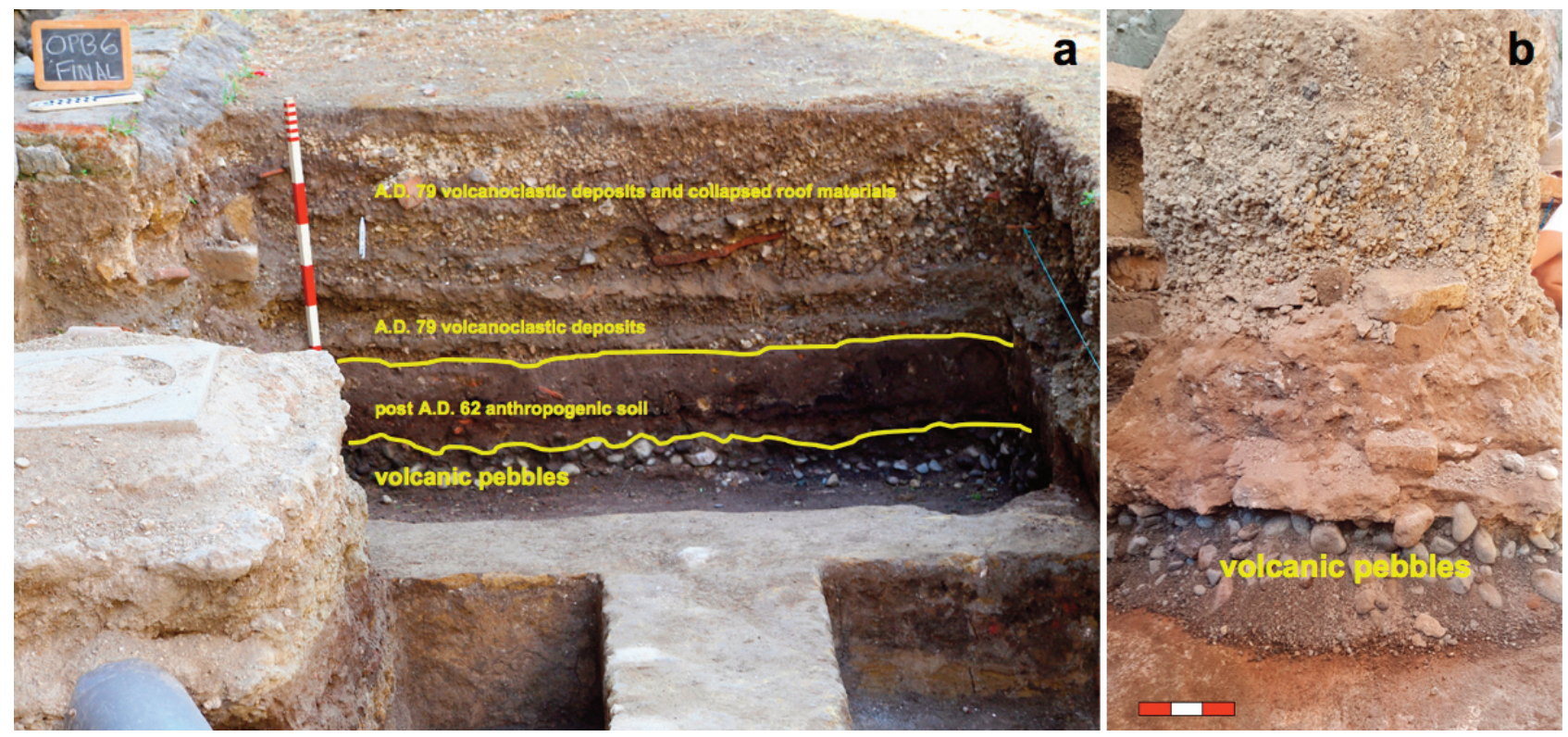

FIGURE 3. Representative stratigraphy of the Oplontis $B$, with the investigated pebbles at the base of the excavation (a) and a close up of the volcanic pebbles (b); the overall scale bar is $30 \mathrm{~cm}$.

by the A.D. 79 pyroclastic deposits, which are also mixed with collapsed roof materials in the uppermost levels. A similar stratigraphic framework can be seen in the "Villa A" site. The lava pebbles were employed as filling materials and ballasts in the foundations.

The Longola settlement (Figure 1) is a very important site as it represents the first protohistoric perifluvial village discovered in southern Italy [Albore Livadie et al., 2010; Cicirelli and Albore Livadie, 2012], strictly connected with the particular river environments' exploitation of the area of the Sarno river. Among the various objects here discovered, the large amount of lithic pebbles made of volcanic and sedimentary rocks have attracted the attention of the researchers, due to their abundance and their possible use [Balassone et al., 2013] and was already studied by Balassone et al. [2016].

\section{SAMPLES}

Lava pebbles from Oplontis consist of 2 stone findings from the foundations of the swimming pool located in the "Villa A" and 23 samples from the building foundations of the Oplontis $B$ (Table 1). These samples were provided by Geomed s.r.l. Geoarcheologia e Geologia Ambientale in the framework of a "Memorandum of Understanding" with the "Soprintendenza Speciale per i Beni Archeologici di Napoli e Pompei". They are all represented by lavas with a diameter comprised between
4 and $11 \mathrm{~cm}$ (Table 1 and Figure 4). At macroscopic scale, they are light brown to light grey in colour, and can be well rounded up to more irregular in shape (Figure 4); few of them can also show a vacuolar texture; some alteration patinas on surfaces of the samples can be rarely detected.

\section{ANALYTHICAL METHODS}

All the Oplontis samples were cut into small slabs for thin sections and small representative fragments were crushed and powdered for whole-rock chemical analyses. Modal mineralogy and petrography were performed by using a polarizing optical microscope (Nikon Optiphot2-Pol). Whole-rock chemistry was determined at Activation Laboratories LTD (Ancaster, Canada). Major elements were analysed by ICP-OES (Inductively Coupled Plasma-Optical Emission Spectrometry) using a Thermo Jarrell-Ash ENVIRO II ICP. Trace elements were determined by ICP-MS (Inductively Coupled Plasma-Mass Spectrometry) with a Perkin Elmer SCIEX ELAN 6000 ICP-MS. The uncertainty is less than 3\% for major oxides, less than 15\% for Co, Y, $\mathrm{Zr}$ and $\mathrm{Tb}$, and less than 5\% for all other trace elements (see www.actlabs.com for the precision of the method). For sake of comparison, we have also considered the petrographic and geochemical data of similar Longola samples as reported by Balassone et al. [2016], already analysed with the same procedure and in the same laboratory.

In the online supplementary material (OSM1, OSM2), 


\section{OPLONTIS lava pebbles}

$\begin{array}{cccccc}\text { Sample } & \text { Site } & \begin{array}{c}\text { Major axe } \\ (\mathrm{cm})\end{array} & \begin{array}{c}\text { Minor axe } \\ (\mathrm{cm})\end{array} & \begin{array}{c}\text { Mineralogical } \\ \text { paragenesis }\end{array} & \text { Porph }\end{array}$

Basic-intermediate slightly silica undersaturated lavas

\begin{tabular}{|c|c|c|c|c|c|c|}
\hline OPL2 & Oplontis B & 6.8 & 4.7 & $\mathrm{Pl}, \mathrm{Ol}, \mathrm{Cpx}, \mathrm{Opq}, \mathrm{Lc}$ & MP & MV \\
\hline OPL16 & Oplontis B & 7.2 & 4.6 & $\mathrm{Pl}, \mathrm{Ol}, \mathrm{Cpx}, \mathrm{Opq}, \mathrm{Lc}$ & HP & PV \\
\hline OPL19 & Oplontis $B$ & 5.2 & 3.6 & $\mathrm{Pl}, \mathrm{Ol}, \mathrm{Cpx}, \mathrm{Opq}, \mathrm{Lc}$ & $\mathrm{HP}$ & HV \\
\hline OPL12 & Oplontis B & 9.9 & 5.4 & $\mathrm{Pl}, \mathrm{Ol}, \mathrm{Cpx}, \mathrm{Opq}, \mathrm{Lc}$ & PP & HV \\
\hline OPL17 & Oplontis B & 6.6 & 4.7 & Pl, Ol, Cpx, Opq, Lc & PP & HV \\
\hline OPL25 & Oplontis $B$ & 6.5 & 4.2 & $\mathrm{Pl}, \mathrm{Ol}, \mathrm{Cpx}, \mathrm{Opq}, \mathrm{Lc}$ & HP & PV \\
\hline OPL4 & Oplontis B & 6.5 & 4.7 & $\mathrm{Pl}, \mathrm{Ol}, \mathrm{Cpx}, \mathrm{Opq}, \mathrm{lc}, \mathrm{Bi} / \mathrm{Phl}, \pm \mathrm{Kf}$ & SA & PV \\
\hline OPL7 & Oplontis B & 6.0 & 4.7 & Pl, Ol, Cpx, Opq, Bi/Phl & $\mathrm{HP}$ & PV \\
\hline OPL21 & Oplontis B & 5.5 & 3.9 & $\mathrm{Pl}, \mathrm{Ol}, \mathrm{Cpx}, \mathrm{Opq}$ & HP & HV \\
\hline \multicolumn{7}{|c|}{ Trachy-phonolite lavas } \\
\hline OPL1 & Oplontis B & 6.1 & 4.8 & Kf, Cpx, Opq, Foid, \pm Pl & MP & MV \\
\hline OPL3 & Oplontis B & 9.8 & 7.3 & Kf, Cpx, Opq, Foid, \pm Pl & SA & MV \\
\hline OPL5 & Oplontis B & 8.2 & 5.8 & Kf, Cpx, Opq, Foid, \pm Pl & SA & PV \\
\hline OPL6 & Oplontis B & 7.6 & 6.4 & Kf, Cpx, Opq, Foid, \pm Pl & MP & PV \\
\hline OPL8 & Oplontis B & 8.6 & 6.5 & Kf, Cpx, Opq, Foid,Tit, \pm Pl & MP & PV \\
\hline OPL9 & Oplontis B & 8.9 & 3.7 & Kf, Cpx, Opq, Foid, \pm Pl & SA & PV \\
\hline OPL10 & Oplontis B & 5.0 & 3.5 & Kf, Cpx, Opq, Foid, \pm Pl & SA & PV \\
\hline OPL11 & Oplontis B & 5.3 & 4.3 & Kf, Cpx, Opq, Foid, \pm Pl & PP & PV \\
\hline OPL13 & Oplontis B & 6.4 & 4.5 & Kf, Cpx, Opq, Foid,Tit, \pm Pl & PP & MV \\
\hline OPL14 & Oplontis B & 7.9 & 5.4 & Kf, Cpx, Opq, Foid, \pm Pl & SA & PV \\
\hline OPL15 & Oplontis B & 6.4 & 4.1 & Kf, Cpx, Opq, Foid, \pm Pl & SA & PV \\
\hline OPL18 & Oplontis B & 6.8 & 5.4 & Kf, Cpx, Opq, Foid Tit, \pm Pl & SA & PV \\
\hline OPL22 & Oplontis B & 7.8 & 7.4 & Kf, Cpx, Opq, Bi, Foid, \pm Pl & PP & PV \\
\hline OPL26 & Oplontis B & 6.6 & 3.5 & Kf, Cpx, Opq, Foid, \pm Pl & SA & PV \\
\hline OPL23 & Villa A & 12.5 & 9.3 & Kf, Cpx, Opq, Bi, Foid, \pm Pl & SA & PV \\
\hline OPL27 & Villa A & 11 & 9.9 & Kf, Cpx, Opq, Foid, \pm Pl & SA & PV \\
\hline
\end{tabular}

TABLE 1. Summary of dimensions, mineralogical paragenesis in order of abundance, porphyricity and vescicularity of the Oplontis lava pebbles. Abbreviations: $\mathrm{Kf}=\mathrm{K}$-feldspar, $\mathrm{Pl}=$ plagioclase, $\mathrm{Lc}=$ leucite, $\mathrm{Cpx}=$ clinopyroxene, $\mathrm{Ol}=$ olivine, $\mathrm{Bi}=\mathrm{bi}-$ otite, $\mathrm{Phl}=$ Phlogopite, $\mathrm{Opq}=$ opaque minerals, Tit = titanite, Foid = feldspathoids (mainly häuyne); Porph = Porphyricity; HP = Highly Porphyritic; MP = Moderately Porphyritic; PP = Poorly Porphyritic; SA = Sub-aphyric; Vesc = Vescicularity; HV = Highly Vesciculated; MV = Moderately Vesciculated; PV = Poorly Vesciculated.

the Oplontis and Longola geochemical datasets of lava pebbles have been also processed by means of Compositional Data Analysis (CoDA) methods [Aitchison, 1986]. Besides the main approach based on igneous petrology (classical thin section petrography and major-trace element bulk rock) CoDA should represent useful reference data for non-petrologists-volcanologists dealing with archaeometric investigations on lithic materials. Following Tolosana Delgado and McKinley [2016], the analysis has been carried out by considering both major and trace elements. This can be done by means of a log centred transformation (clr) [Aitchison, 1982] applied to the dataset represented by the full geochemical compositions. Trace elements have been included in the analysis as amalgamated groups. First, the Oplontis and Longola samples were grouped by means of a cluster analysis computed with Ward's method [Ward, 1963] on isometric log ratio coordinates (ilr) [Egozcue et al., 2003] obtained from raw geochemical data. The ilr coordinates have been obtained by means of balances, which are based on a sequential binary partition of the compositional dataset [Egozcue and Pawlowsky-Glahn, 2005]. The sample means of the clusters have been compared through a Multivariate ANalysis Of VAriance (MANOVA), computed on ilr principal components. The differences between groups have been described by means of a geometric mean barplot [MartínFernández et al., 2015], where the geometrical mean for each component in each group is compared (as a log-ratio) with the general geometric mean. The ilr components have been also considered to evaluate the atypi- 


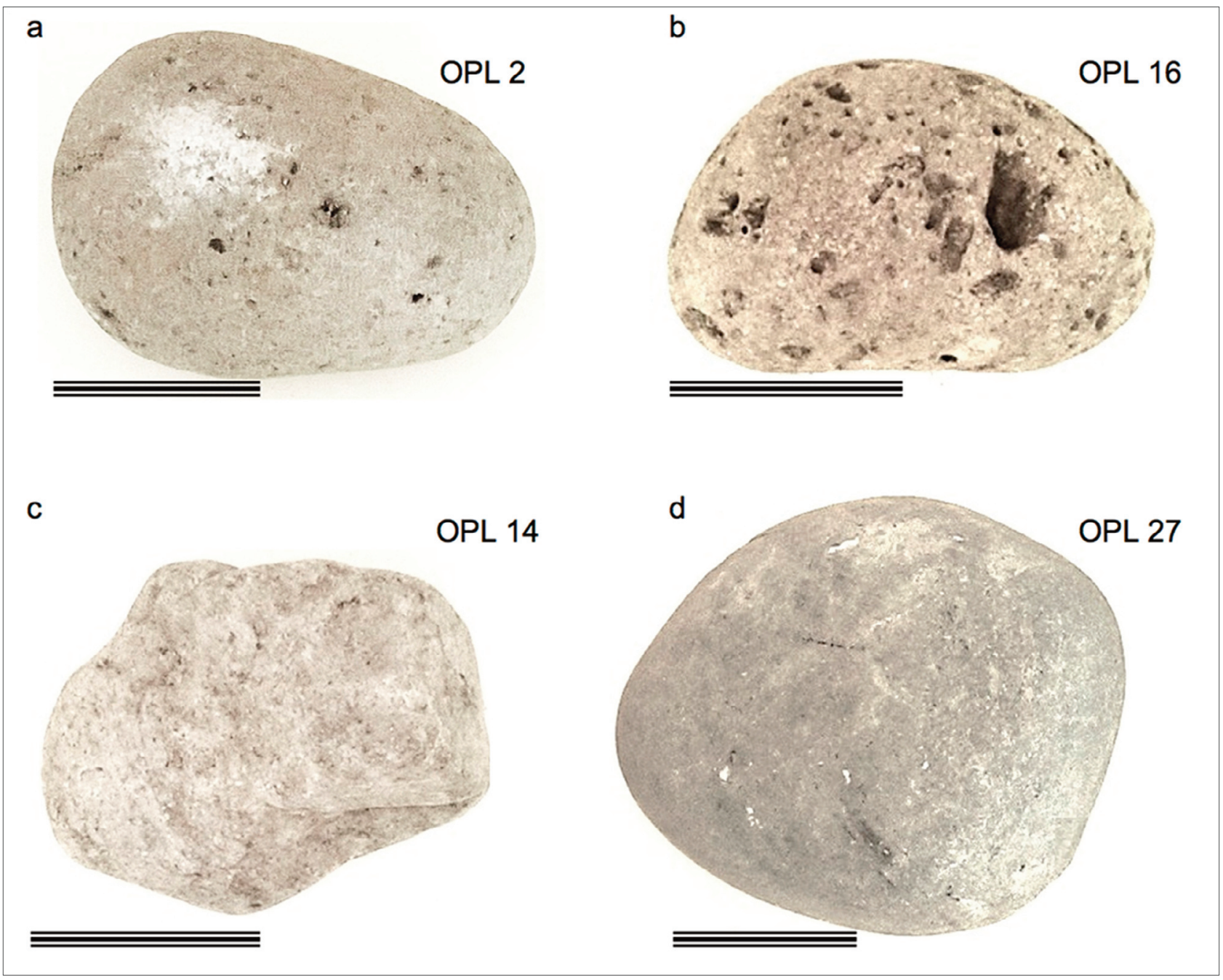

FIGURE 4. Macroscopic features of selected Oplontis lava pebbles, representative of the basic-intermediate slightly silica undersaturated lavas $(\mathrm{a}, \mathrm{b})$ and trachy-phonolite lavas (c, d). The scale bars correspond to $3 \mathrm{~cm}$ in length.

cality of the samples with respect to the clusters to which they belong. In particular, the atypicality has been checked by means of squared Mahalanobis distances computed with a robust estimation of covariance and means of each group [Filzmoser and Hron, 2008]. Subsequently, the geochemical data were analysed through a Relative Variation Biplots (RVB) [Aitchison and Greenacre, 2002] computed on clr coordinates. Within the RVB the samples were symbolised according to both archaeological site and grouping.

\section{RESULTS}

Combining petrography (Figures 5,6 and Table 1) with major elements abundances (Tables 2, 3) the new data set of lava pebbles from Oplontis closely match those from Longola lava samples [Balassone et al., 2016] in the Total Alkali-Silica classification diagram (Figure 7). The overall data define two main groups within the slightly silica undersaturated series of the Somma-Vesuvius extrusives preceding the A.D. 79 Vesuvius eruption [Peccerillo, 2005; Di Renzo et al., 2007; Santacroce et al., 2008; Avanzinelli et al., 2017, and references therein]: (i) basic-intermediate volcanic rocks (mainly phonolitic tephrites to basaltic trachyandesites) and (ii) trachyphonolites comprising different lithotypes in terms of modal mineralogy and textures. Coherently with these results, the cluster analysis performed with CoDA (see analythical methods and Supplementary Material), clearly separate two clusters, closely matching the above separated petrographic groups.

\subsection{PETROGRAPHIC DATA OF THE OPLONTIS LAVA PEBBLES}

The basic-intermediate group is characterized by poorly to highly porphyritic lavas (Table 1, Figure 5). Groundmass is microcrystalline to cryptocrystalline, mostly intergran- 

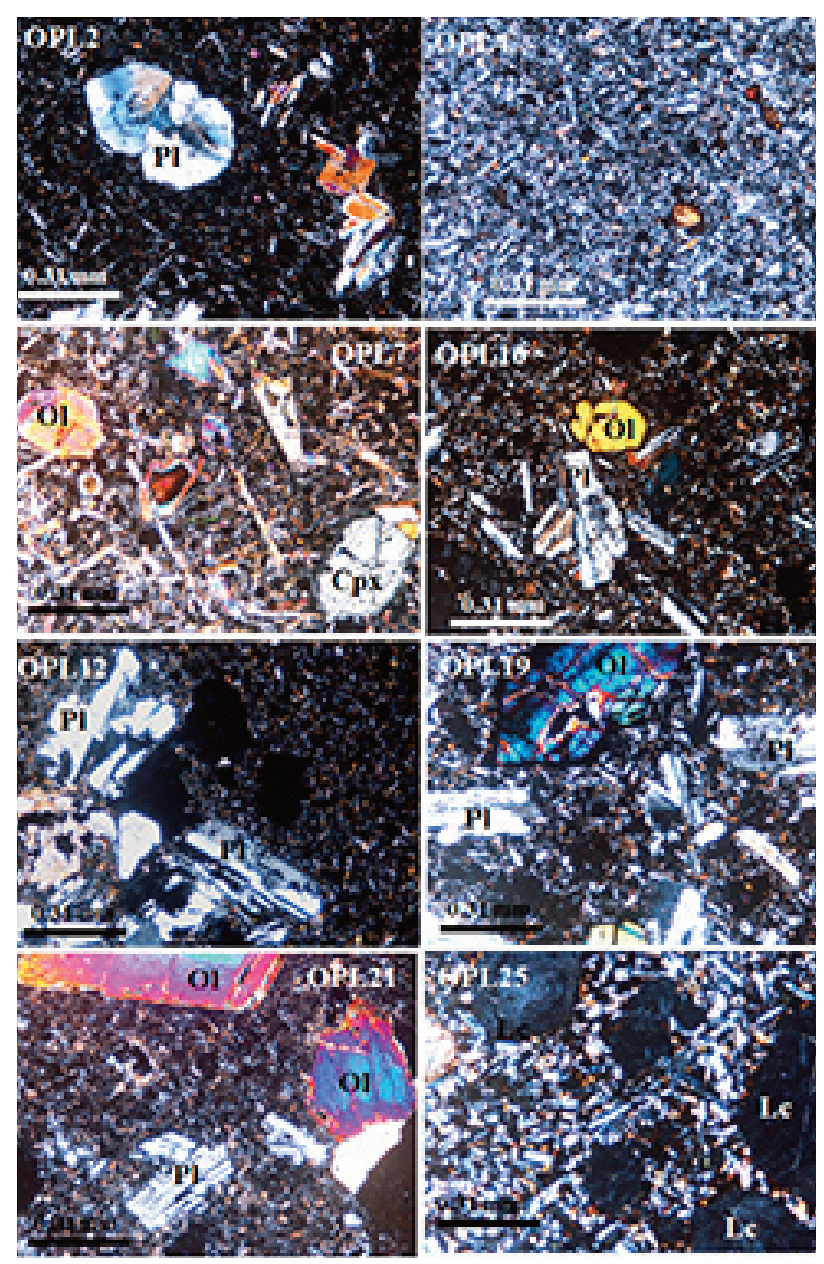

FIGURE 5. Thin section petrography of representative basic-intermediate slightly silica undersaturated lava pebbles of Oplontis.

ular, consisting of the same fundamental minerals mainly found as phenocrysts: plagioclase, clinopyroxene and olivine (frequently oxidized). Leucite occurs as feldspathoid in nearly all the samples whereas interstitial K-feldspar, biotite and/or phlogopite are rare (Table 1). Opaque minerals represent the main accessory phases.

Trachy-phonolite samples (Table 1; Figure 6) are generally sub-aphyric to poorly porphyritic. Groundmass is feldspathic with felty texture and/or pilotaxitic. The fundamental minerals are represented by sanidine and clinopyroxene \pm plagioclase. Different felspathoid phases, mainly interstitial leucite or hauyne can be present. Biotite also occurs. Accessory minerals are represented by ubiquitous opaque minerals and subordinate titanite.

\subsection{GEOCHEMISTRY OF OPLONTIS AND LONGOLA LAVA PEBBLES}

Samples of the basic-intermediate slightly silica undersaturated series (Table 2; Figure 7) are comprised within a wide range of $\mathrm{K}_{2} \mathrm{O} / \mathrm{Na}_{2} \mathrm{O}$ ratios $(1.2-4.3)$. $\mathrm{MgO}$ and $\mathrm{CaO}$ contents vary from 2.7-6.7 wt $\%$ and 6.9-11.8

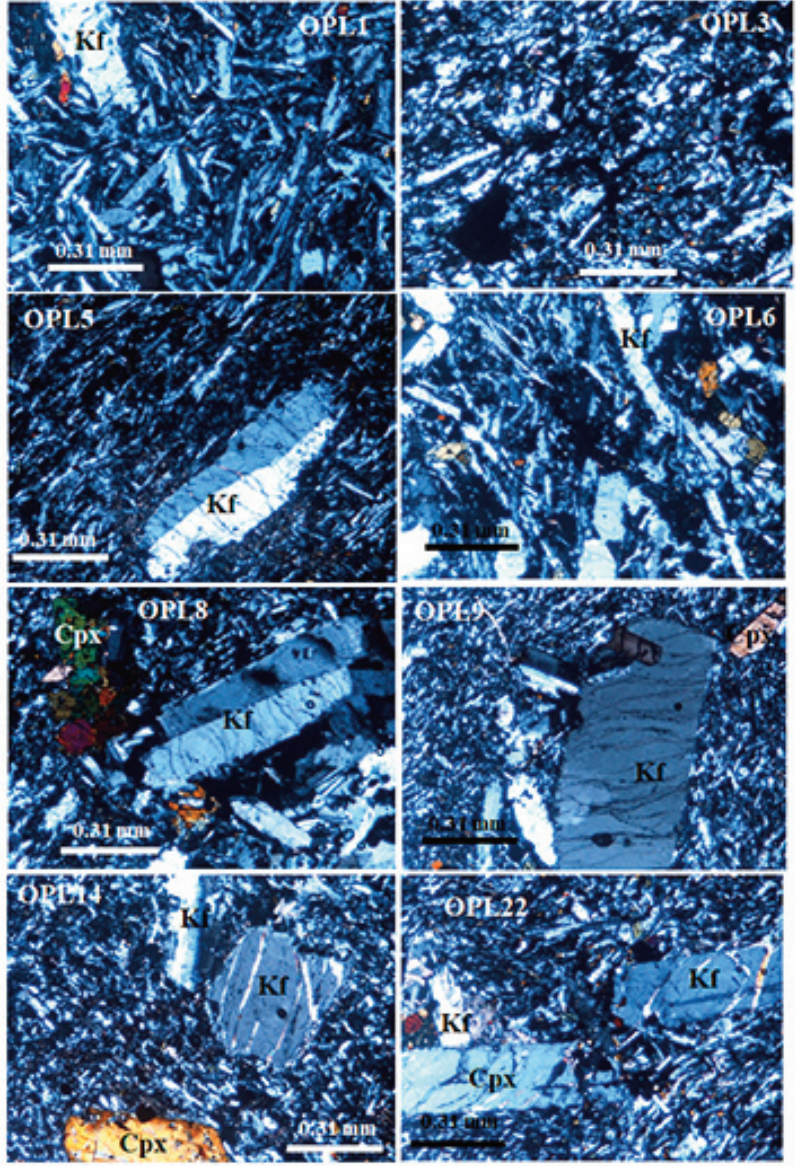

FIGURE 6. Thin section petrography of representative trachyphonolite lava pebbles of Oplontis.

wt $\%$ respectively for the Oplontis samples, whereas Longola samples show $\mathrm{CaO}$ from 7.3 to $9.0 \mathrm{wt} \%$ and $\mathrm{MgO}$ from 1.5 to $5.9 \mathrm{wt} \%$ [Balassone et al., 2016]. This petrographic group mainly shows trace elements distributions compatible with the extrusives of Somma-Vesuvius erupted before $8 \mathrm{ka}$ BP as emphasized by the $\mathrm{Rb}$ and $\mathrm{Th}$ vs. $\mathrm{SiO}_{2}$ diagrams (Figure 8 ). Such basic-intermediate lava pebbles have the same chemical features of several flows outcropping nowadays throughout the southern and south-eastern flanks of the volcano [Santacroce and Sbrana, 2003].

Trachy-phonolite lava pebbles from Oplontis are characterized by a $\mathrm{K}_{2} \mathrm{O} / \mathrm{Na}_{2} \mathrm{O}$ ratio ranging between 1.6 and 2.2 (Table 3) mostly coinciding with the variability of Longola ratios (1.7-2.1; Balassone et al. 2016). The overall group of trachy-phonolites shows a very restricted and low content of Mg0 (0.2- $0.5 \mathrm{wt} \%$ ), excepting for two Longola poorly evolved "trachytes" with $\mathrm{MgO}$ of 1.0 and $1.6 \mathrm{wt} \%$ respectively [Balassone et al., 2016]. CaO is between 2.3 and $3.1 \mathrm{wt} \%$ and only one Longola sample shows a higher $\mathrm{CaO}$ value of $4.2 \mathrm{wt} \%$ 


\begin{tabular}{|c|c|c|c|c|c|c|c|c|c|}
\hline \multicolumn{10}{|c|}{ Basic-intermediate slightly silica undersaturated lava pebbles } \\
\hline & OPL2 & OPL4 & OPL7 & OPL12 & OPL16 & OPL17 & OPL19 & OPL21 & OPL25 \\
\hline $\mathrm{SiO}_{2}$ & 52,16 & 52,56 & 50,64 & 51,12 & 50,38 & 51,40 & 50,77 & 49,15 & 49,44 \\
\hline $\mathrm{Al}_{2} \mathrm{O}_{3}$ & 18,05 & 18,40 & 14,46 & 17,94 & 17,41 & 17,69 & 17,83 & 14,60 & 16,99 \\
\hline $\mathrm{Fe}_{2} \mathrm{O}_{3}$ & 8,05 & 7,65 & 7,47 & 8,50 & 7,88 & 7,67 & 7,82 & 7,89 & 8,16 \\
\hline MnO & 0,13 & 0,12 & 0,13 & 0,09 & 0,13 & 0,13 & 0,12 & 0,16 & 0,13 \\
\hline $\mathrm{MgO}$ & 3,82 & 3,13 & 7,06 & 2,72 & 4,52 & 3,21 & 3,89 & 6,75 & 5,42 \\
\hline $\mathrm{CaO}$ & 7,14 & 6,99 & 11,80 & 7,22 & 7,84 & 7,28 & 6,93 & 10,34 & 10,23 \\
\hline $\mathrm{Na}_{2} \mathrm{O}$ & 3,37 & 2,20 & 2,03 & 3,06 & 2,93 & 2,69 & 2,93 & 1,41 & 1,93 \\
\hline $\mathrm{K}_{2} \mathrm{O}$ & 4,40 & 6,06 & 4,55 & 4,21 & 5,19 & 4,46 & 6,53 & 5,28 & 5,39 \\
\hline $\mathrm{TiO}_{2}$ & 0,95 & 0,94 & 0,81 & 0,94 & 0,91 & 0,93 & 0,92 & 0,83 & 1,00 \\
\hline $\mathrm{P}_{2} \mathrm{O}_{5}$ & 0,70 & 0,67 & 0,61 & 0,73 & 0,75 & 0,73 & 0,73 & 0,54 & 0,73 \\
\hline LOI & 0,77 & 1,60 & 0,64 & 3,51 & 2,24 & 2,67 & 1,23 & 1,61 & 0,89 \\
\hline Total & 99,54 & 100,30 & 100,20 & 100,00 & 100,20 & 98,86 & 99,68 & 98,56 & 100,30 \\
\hline $\mathrm{K}_{2} \mathrm{O} / \mathrm{Na}_{2} \mathrm{O}$ & 1,3 & 2,8 & 2,2 & 1,4 & 1,8 & 1,7 & 2,2 & 3,7 & 2,8 \\
\hline $\mathrm{V}$ & 204 & 223 & 247 & 206 & 210 & 199 & 176 & 232 & 230 \\
\hline $\mathrm{Cr}$ & $<20$ & 30 & 180 & $<20$ & 50 & $<20$ & 40 & 250 & 60 \\
\hline Co & 23 & 22 & 26 & 21 & 28 & 23 & 25 & 29 & 28 \\
\hline $\mathrm{Ni}$ & $<20$ & 20 & 60 & $<20$ & 40 & $<20$ & 30 & 70 & 40 \\
\hline $\mathrm{Rb}$ & 196 & 176 & 185 & 154 & 315 & 137 & 424 & 224 & 283 \\
\hline Sr & 805 & 841 & 628 & 836 & 761 & 803 & 760 & 654 & 773 \\
\hline Y & 21 & 21 & 19 & 21 & 22 & 21 & 21 & 21 & 23 \\
\hline $\mathrm{Zr}$ & 196 & 245 & 159 & 217 & 211 & 205 & 199 & 156 & 168 \\
\hline $\mathrm{Nb}$ & 27 & 31 & 16 & 31 & 28 & 29 & 26 & 18 & 21 \\
\hline Ва & 1898 & 2075 & 1456 & 1896 & 1748 & 1906 & 1703 & 1557 & 1488 \\
\hline la & 42 & 48 & 43 & 46 & 39 & 46 & 39 & 33 & 38 \\
\hline $\mathrm{Ce}$ & 89 & 99 & 90 & 91 & 83 & 92 & 83 & 70 & 80 \\
\hline $\operatorname{Pr}$ & 10,0 & 11,2 & 10,6 & 10,4 & 9,9 & 10,5 & 9,7 & 8,2 & 9,8 \\
\hline $\mathrm{Nd}$ & 37 & 42 & 41 & 39 & 39 & 40 & 38 & 33 & 39 \\
\hline $\mathrm{Sm}$ & 7,9 & 8,6 & 8,8 & 8 & 8,4 & 8,1 & 8,2 & 7,4 & 8,7 \\
\hline $\mathrm{Eu}$ & 2,0 & 2,1 & 2,2 & 2,0 & 2,0 & 1,9 & 2,0 & 1,9 & 2,2 \\
\hline $\mathrm{Gd}$ & 6,3 & 6,5 & 6,9 & 6,3 & 6,7 & 6,5 & 6,7 & 6 & 7,2 \\
\hline $\mathrm{Tb}$ & 0,9 & 0,9 & 0,9 & 0,9 & 0,9 & 0,9 & 0,9 & 0,8 & 1,0 \\
\hline Dy & 4,6 & 4,7 & 4,5 & 4,6 & 4,8 & 4,6 & 4,7 & 4,5 & 5,2 \\
\hline Ho & 0,8 & 0,8 & 0,8 & 0,8 & 0,9 & 0,8 & 0,8 & 0,8 & 0,9 \\
\hline $\mathrm{Er}$ & 2,1 & 2,2 & 2 & 2,1 & 2,1 & 2,2 & 2,2 & 2,1 & 2,4 \\
\hline $\mathrm{Tm}$ & 0,33 & 0,3 & 0,29 & 0,3 & 0,32 & 0,32 & 0,3 & 0,32 & 0,34 \\
\hline $\mathrm{Yb}$ & 2,0 & 2,0 & 1,8 & 2,0 & 2,0 & 2,0 & 1,9 & 2,0 & 2,0 \\
\hline $\mathrm{Lu}$ & 0,30 & 0,31 & 0,28 & 0,32 & 0,32 & 0,32 & 0,30 & 0,31 & 0,32 \\
\hline $\mathrm{Hf}$ & 4,5 & 5,4 & 3,7 & 4,7 & 4,8 & 4,6 & 4,6 & 3,5 & 4,2 \\
\hline Та & 1,5 & 1,7 & 0,8 & 1,5 & 1,5 & 1,6 & 1,4 & 1,0 & 1,2 \\
\hline Th & 17 & 20 & 14 & 17 & 14 & 18 & 14 & 11 & 12 \\
\hline $\mathrm{U}$ & 4,2 & 6,4 & 4,1 & 5,6 & 4,2 & 5,5 & 3,8 & 3,8 & 3,7 \\
\hline
\end{tabular}

TABLE 2. Whole-rock major elements oxides (wt\%) and trace elements (ppm) composition of the basic-intermediate slightly silica undersaturated lava pebbles of Oplontis. 
Trachy-phonolites lava pebbles

OPL1 OPL3 OPL5 OPL6 OPL8 OPL9 OPL10 OPL11 OPL13 OPL14 OPL15 OPL18 OPL22 OPL23 OPL26 OPL27

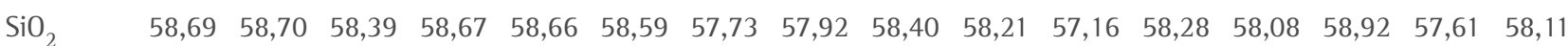

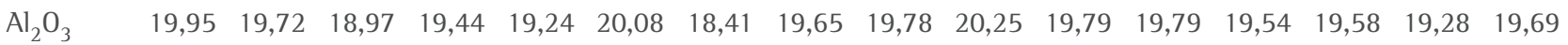

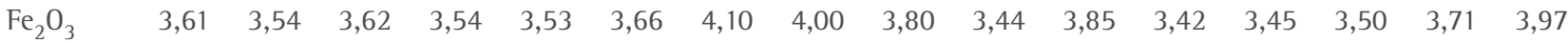

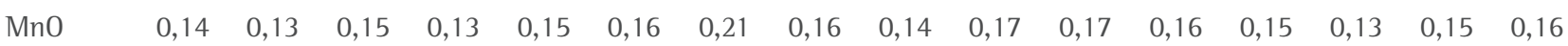

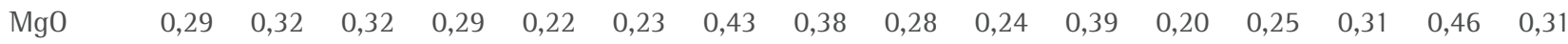

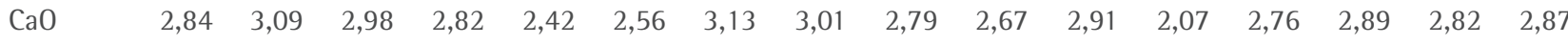

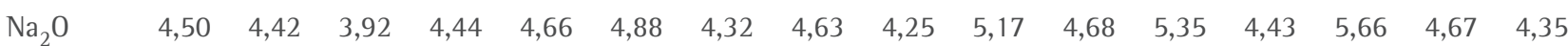

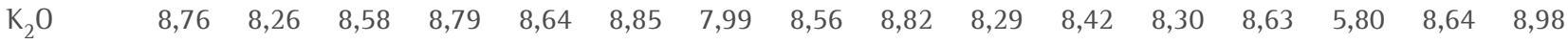

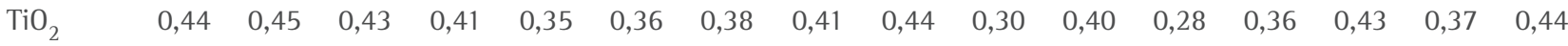

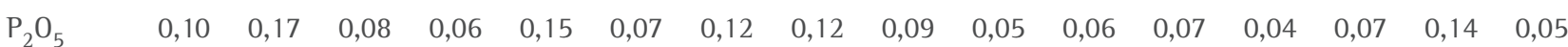

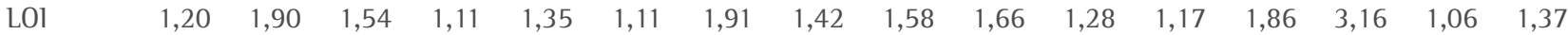

Total 100,50100,70 98,97 99,70 99,38 100,50 98,73 100,30100,40100,40 99,10 99,10 99,55 $100,40 \quad 98,91 \quad 100,30$

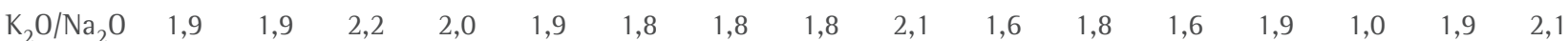
$\begin{array}{lllllllllllllllll}\mathrm{V} & 66 & 68 & 68 & 63 & 54 & 54 & 63 & 64 & 64 & 46 & 63 & 45 & 53 & 57 & 61 & 66\end{array}$

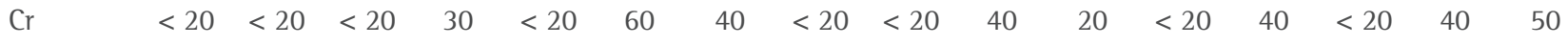
$\begin{array}{llllllllllllllll}\mathrm{Co} & 3 & 3 & 3 & 3 & 3 & 3 & 6 & 4 & 3 & 3 & 4 & 2 & 3 & 3 & 4\end{array}$ $\mathrm{Ni}<20<20<20<20<20 \quad 30<20<20<20 \quad 20<20<20<20<20<20 \quad 20$

$\begin{array}{lllllllllllllllll}\mathrm{Rb} & 357 & 316 & 371 & 377 & 385 & 420 & 346 & 387 & 410 & 377 & 380 & 449 & 380 & 221 & 412 & 357\end{array}$

$\begin{array}{lllllllllllllllll}\mathrm{Sr} & 530 & 557 & 536 & 526 & 376 & 378 & 420 & 434 & 508 & 241 & 403 & 204 & 366 & 507 & 388 & 516\end{array}$

$\begin{array}{lllllllllllllllll}Y & 22 & 21 & 23 & 18 & 17 & 20 & 19 & 22 & 23 & 27 & 23 & 19 & 25 & 23 & 14 & 26\end{array}$

$\begin{array}{lllllllllllllllll}\mathrm{Zr} & 365 & 353 & 351 & 292 & 325 & 341 & 293 & 357 & 358 & 420 & 378 & 277 & 388 & 356 & 277 & 389\end{array}$

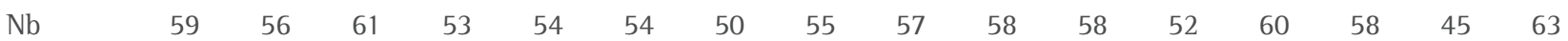

$\begin{array}{lllllllllllllllll}\text { Ва } & 366 & 439 & 485 & 364 & 163 & 163 & 281 & 313 & 324 & 81 & 257 & 48 & 168 & 362 & 240 & 362\end{array}$

$\begin{array}{lllllllllllllllll}\mathrm{La} & 77 & 73 & 77 & 73 & 80 & 82 & 75 & 77 & 80 & 87 & 81 & 92 & 83 & 76 & 76 & 80\end{array}$

$\begin{array}{lllllllllllllllll}\text { Ce } & 144 & 139 & 146 & 138 & 146 & 148 & 139 & 141 & 151 & 152 & 149 & 161 & 149 & 143 & 140 & 150\end{array}$

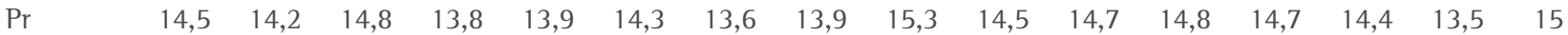

$\begin{array}{lllllllllllllllll}\mathrm{Nd} & 48 & 47 & 49 & 47 & 44 & 45 & 44 & 46 & 50 & 45 & 47 & 46 & 46 & 47 & 42 & 50\end{array}$

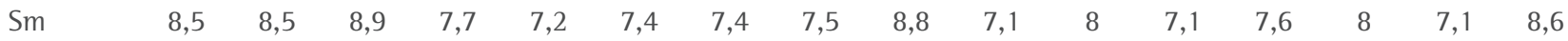

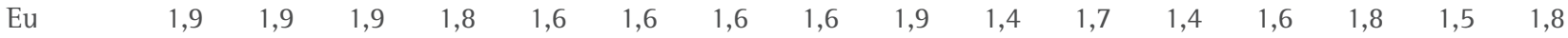

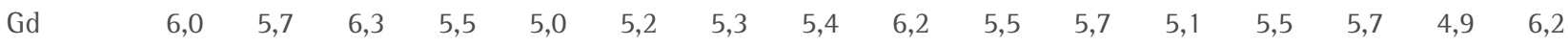

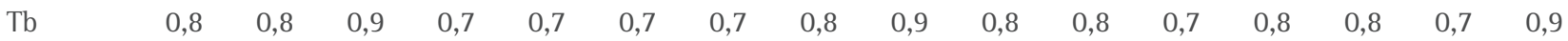

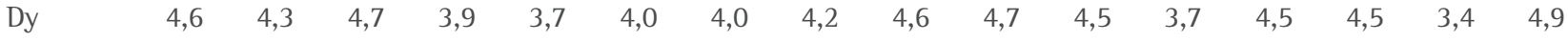

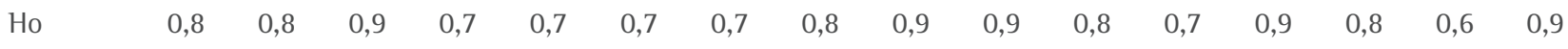

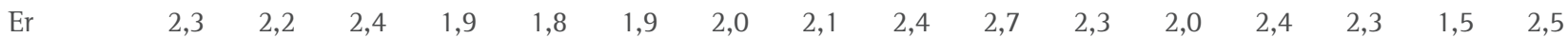

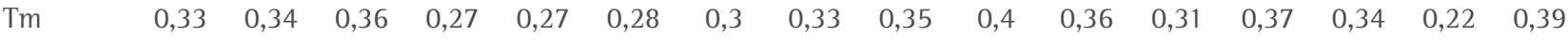

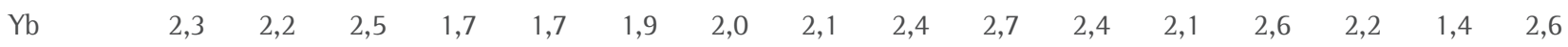

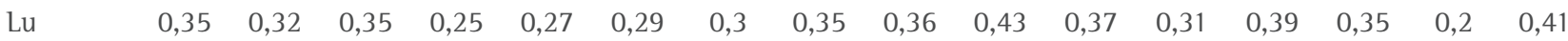

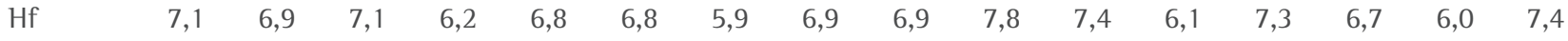

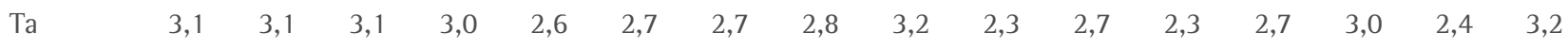

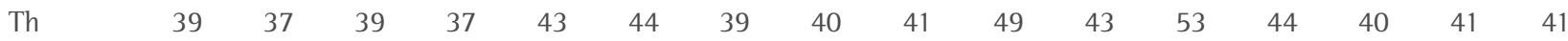

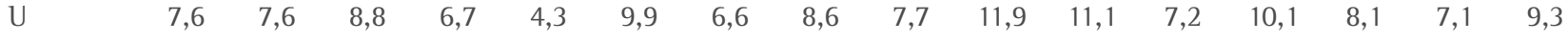

TABLE 3. Whole-rock major elements oxides (wt\%) and trace elements (ppm) composition of the trachy-phonolite lava pebbles of Oplontis. 


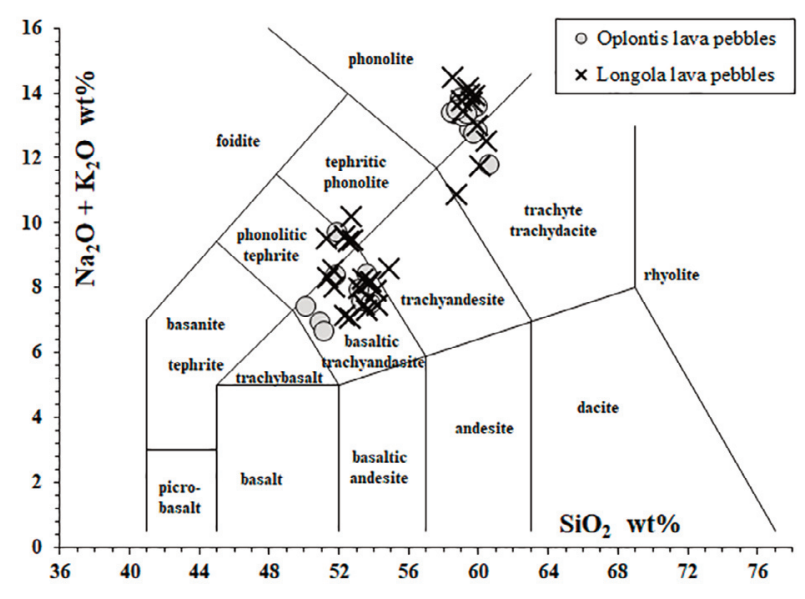

FIGURE 7. The Total Alkali-Silica classification diagram [Le Bas et al., 1986] for the whole Oplontis and Longola [Balassone et al., 2016] lava pebbles.

[Balassone et al., 2016]. Trachy-phonolites from Oplontis and Longola show a relatively restricted ranges of HFSE (e.g. Th 35-53 ppm, Nb 45-76 ppm, Zr 277-472 $\mathrm{ppm}$ ) and a wider spectra of LILE (e.g. Rb 221-449 ppm, Sr 178-733 ppm) and REE (e.g. La 73-105 ppm, Ce 138202 ppm, Nd 42-71 ppm) abundances. The overall major and trace elements distribution of the trachy-phonolite pebbles emphasizes a strong affinity with the pyroclastic evolved products erupted by Somma-Vesuvius before $8 \mathrm{ka}$ BP (Figure 8). Nevertheless, source lava counterparts of the trachy-phonolite pebbles were never pointed out as lithostratigraphic units present in outcrops among the products of the Somma-Vesuvius volcano [Santacroce and Sbrana, 2003].

\section{DISCUSSION}

The basic-intermediate lavas (mainly phonolitic tephrites to basaltic trachyandesites) of the Oplontis and Longola samples are petrochemically similar to the Somma-Vesuvius lavas erupted before $8 \mathrm{ka} \mathrm{BP}$, still largely present on the southern and south-eastern flanks of the stratovolcano. By contrast, trachy-phonolite lava findings at Oplontis and Longola archaeological sites are compatible with magmas erupted by the volcano as pyroclastic products before $8 \mathrm{ka} \mathrm{BP}$, but still lacking as counterparts in the lava lithotypes mapped as volcanic formations of the Somma-Vesuvius [Santacroce and Sbrana, 2003].

The lava pebbles found in the foundations (ballast) of the Villas of Oplontis most probably come from the ancient coastal shoreline, as these houses were built along the cliff of the present-day town of Torre Annunziata. In the Roman period this shoreline had to be constituted by a wide collection of lava pebbles from several lava flows of the ancient (pre A.D. 79 eruption) Somma-Vesuvius activity. Among these pebbles of the ancient shoreline, some lithic component (i.e. lavas) included within the oldest pyroclastic deposits could be also present. In any case, the investigated trachy-phonolite pebbles represent the products of an old effusive activity of the Somma-Vesuvius which is not present anymore among the mapped lithostratigraphic units. According to deep borehole data (Trecase 1 well, Brocchini et al., 2001; Camaldoli della Torre well, Di Renzo et al., 2007) there seems to be no evidence of clear trachyte/trachyphonolite lavas under the A.D. 79 eruption, at least in the southern sector of Vesuvius. In this way, for the Oplontis site, which is located in the same southern sector of the volcano, the possibility of a wide trachyphonolite lava flow in the proximity of this settlement can be therefore excluded. Nevertheless, it is worth noting that trachyte lavas were recorded by R. Sulpizio (pers. comm.) in the northern outer sectors of the Mt. Somma rim, linked to an effusive activity occurred before the "Pomici di Base" Plinian eruption (ca. 18 ka BP).

In order to rule out other possible sources of the trachy-phonolite lava pebbles, the near trachyte (domes) effusive activity of the Phlegraean Fields [Rosi and Sbrana, 1987; D'Antonio et al., 1999; Melluso et al., 2012] was also taken into account for comparisons.

The trachyte lavas from Phlegraean Fields referred to the pre-caldera phase, such as those outcropping at Punta Marmolite, Cuma and Mount of Procida domes are generally characterized by a different content in major elements [Rosi and Sbrana, 1987; D’Antonio et al., 1999; Pappalardo et al., 1999; Melluso et al., 2012]. In particular, they show a more sodic character $\left(\mathrm{Na}_{2} \mathrm{O}\right.$ between 5.0 and $8.6 \mathrm{wt} \%$ ) and lower $\mathrm{K}_{2} \mathrm{O} / \mathrm{Na}_{2} \mathrm{O}$ ratios (0.7-1.6) than those of the trachy-phonolite pebbles of Oplontis and Longola $\left(\mathrm{Na}_{2} \mathrm{O}\right.$ between 3.8 and $5.3 \mathrm{wt} \% ; \mathrm{K}_{2} \mathrm{O} / \mathrm{Na}_{2} \mathrm{O} 1.6$ and 2.2). Also trace elements distribution of Punta Marmolite and Cuma Phlegraean domes do not match with the trachy-phonolites of the Oplontis and Longola lava samples (Figure 9).

Trachyte lava xenoliths of the Breccia Museo Formation [Rosi and Sbrana, 1987; Fedele et al., 2008] can be also ruled out as a possible provenance on the basis of some geochemical parameters: in particular, they have too high silica $\left(\mathrm{SiO}_{2}\right.$ comprised between 59 and $\left.63 \mathrm{wt} \%\right)$ contents with respect to the investigated trachy-phonolite pebbles of Oplontis and Longola. 


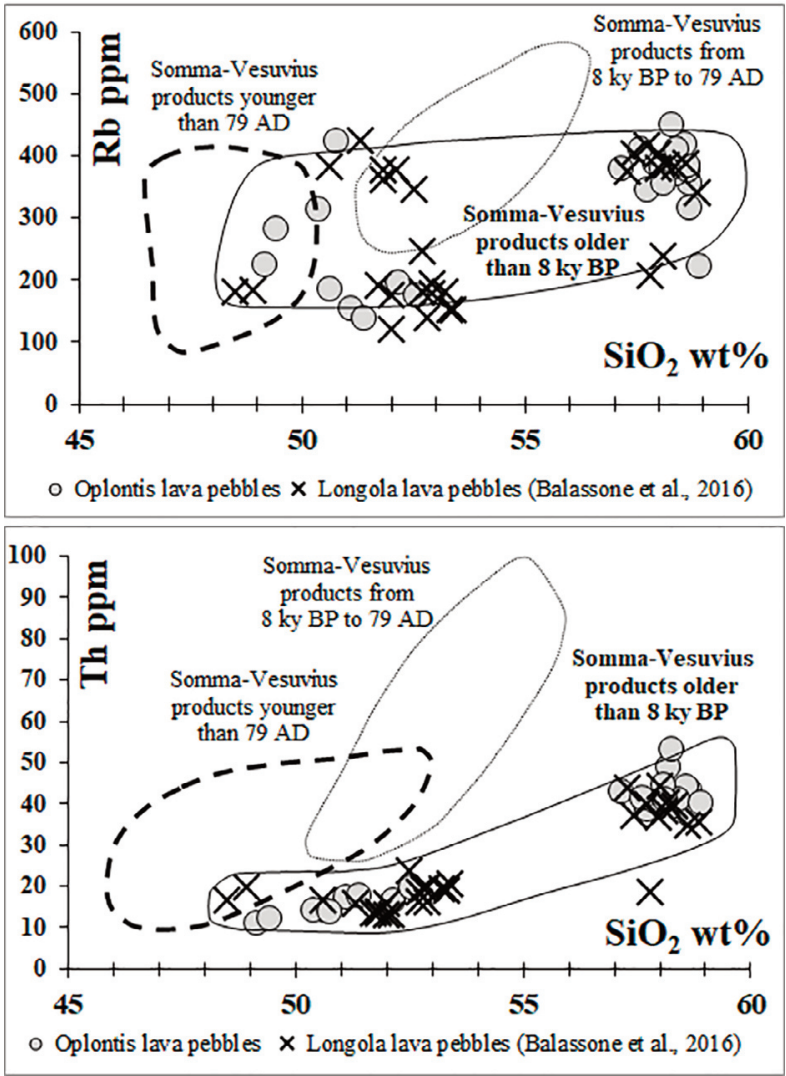

FIGURE 8. Th and $\mathrm{Rb}$ vs $\mathrm{SiO}_{2}$ diagrams for all the Oplontis and Longola lava pebbles compared with literature data from the Somma-Vesuvius volcano [Peccerillo, 2005].

Concerning the younger trachyte/trachyphonolite lavas of the Phlegraean Fields, few outcrops, such as those of Accademia - Mount Olibano and Caprara [D’Antonio et al., 1999; Melluso et al., 2012] show comparable $\mathrm{K}_{2} \mathrm{O} / \mathrm{Na}_{2} \mathrm{O}$ ratios (1.9-2.4), with respect to those of the Longola and Oplontis trachy-phonolites. Trace element distributions reported in Figure 9 concur in ruling out the Mount Olibano and Caprara lavas as source rocks of the investigated trachy-phonolites of Oplontis and Longola whereas the Accademia lava dome, located along the Phlegraean coast, in the central eastern sector of the Gulf of Pozzuoli, show LILE, HFSE and REE abundances which can be compatible with those of the investigated trachy-phonolites (Figure 9). Nevertheless, both Accademia and Mount Olibano trachyte lavas show high $\mathrm{Mg0}$ content (0.8-3.3 wt\%), making it difficult any comparisons with the investigated trachy-phonolite pebbles (0.2- $0.5 \mathrm{wt} \%)$. Also the Caprara lava can be ruled out, due to its high $\mathrm{MgO}(1.1 \mathrm{wt} \%)$ and $\mathrm{CaO}(3.9 \mathrm{wt} \%)$ contents. Finally, combining all major elements data, also the Accademia trachyte is well outside the main group of the trachy-phonolite of Oplontis and Longola lava pebbles (Figure 10). These latter can be therefore definitively
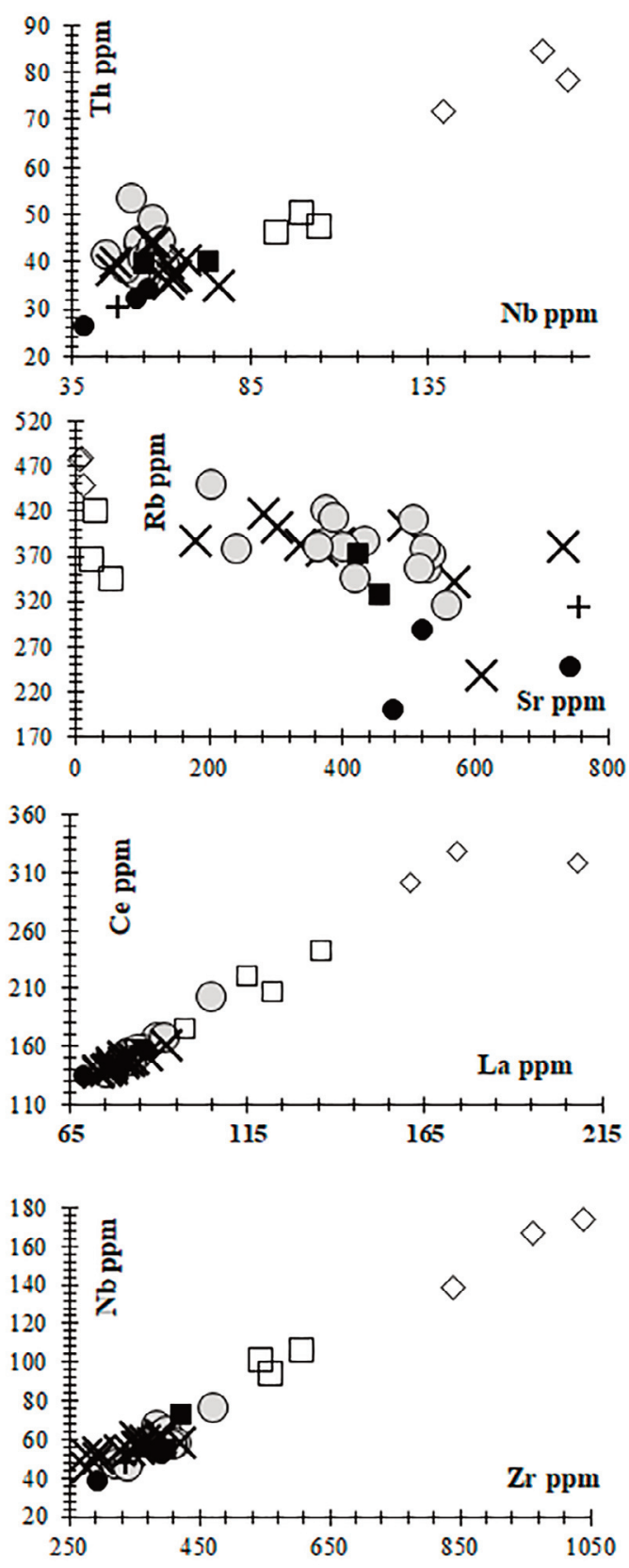

- Oplontis trachy-phonolite pebbles

* Long da trachyphonolite peb bles

- Cuma precaldera tachyte lavas (Pappalardo et al, 1999, Melluso et al. 2012)

- Punta Marmolite pre-caldera trachyte lavas (Pappalardo et al., 1999; Mallus o et 31, 2012)

- Mount Olibano post-caldera trachyte lavas (D'Antonio et al., 1999;

Melluso et al., 2012)

- Accademia post-caldera trachyte lavas (D'Antonio et al., 1999, Melluso ex al, 2012)

- Caprara post-caldera trachyte lava (D'Antonio et al., 1999)

FIGURE 9. Nb vs Th, Sr vs Rb, La vs Ce and $\mathrm{Zr}$ vs Nb diagrams for all the Oplontis and Longola trachy-phonolite lava pebbles compared with literature data.

considered as the effusive counterparts of the same magmas frequently erupted as pyroclastic products during the oldest explosive Mt.Somma activity (i.e. before 8 ka BP), even though an old trachyte or trachy-phonolite effusive 

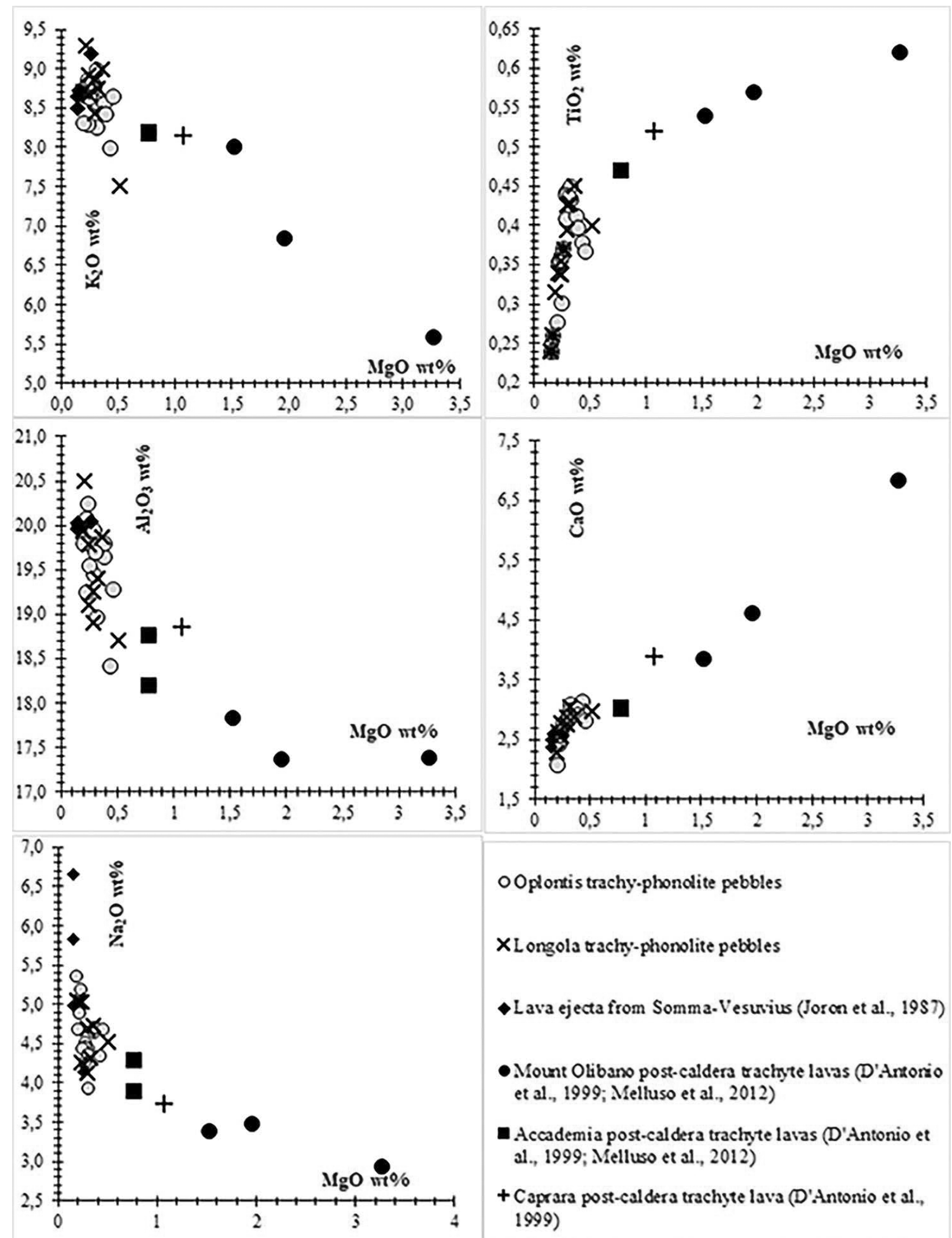

O Oplontis trachy-phondite pebbles

XLongola «achy-phonolite pebbles

- Lava ejecta from Somma-Vesurius (Jorcn et al., 19\$7)

- Mount Olibano post-caldera rachyte lavas (D'Artorio et al., 1999; Melluso et al., 2012)

- Accademia post-cal dera trachyte lavas (D'Antonio et al., 1999; Melluso et al., 2012)

+ Caprara post-caldera trachyte lava (D'Antonio et al., 1999)

FIGURE 10. $\mathrm{MgO}$ vs $\mathrm{K}_{2} \mathrm{O}, \mathrm{CaO}, \mathrm{Na}_{2} \mathrm{O}, \mathrm{TiO}_{2}, \mathrm{Al}_{2} \mathrm{O}_{3}$ diagrams for all the Oplontis and Longola trachy-phonolite lava pebbles compared with literature data.

phase does not find a clear evidence as outcrops of lava flows stricto sensu. We can not speculate if the investigated lava pebbles come from old, now disappeared, lava bodies (and relative autoclastic breccias) or the lithic (i.e. lavas) component of pre A.D. 79 eruption pyroclastic products. 
Presently, witnesses of this Somma-Vesuvius trachyphonolite effusive activity older than 8 ka BP were only identified in lithic lavas within pyroclastic deposits of the volcano. Selected lava ejecta within the Avellino Plinian fall deposit (3.7 Ka BP) and from the top of Mt. Somma [cf. Table 3.7 of Joron et al., 1987] closely match the trachy-phonolite lava pebbles as concerning major element distributions (Figure 10).

\section{FINAL REMARKS}

The trachy-phonolite lava pebbles detected in the Oplontis and Longola archaeological sites show a strong affinity (mineralogy and major-trace element fingerprint) with the magmas erupted as pyroclastics during the Plinian Somma-Vesuvius explosive events older than $8 \mathrm{ka}$ BP. The origin of these lava pebbles is therefore to be searched from some of the oldest subaerial effusive activity of the volcano even if they do not match with any mapped Somma-Vesuvius lithostratigraphic units available from literature data. The Roman shoreline of Torre Annunziata where the private villas and public commercial structures of the ancient Oplontis were built on, should have preserved some trachy-phonolite lavas as pebbles. Similar trachy-phonolite lithic (lava) ejecta found within some of the oldest Plinian eruptions of the Somma-Vesuvius strongly corroborate the hypothesis that magmas with this composition were also erupted as lava flows, then disrupted during some explosive events. Although we can not conjecture the trachy-phonolite lava pebbles come from lava flows stricto sensu (comprising their autoclastic breccias) or the lithic (lavic) components within pre A.D. 79 eruption pyroclastic products, they clearly represent witnesses of an old effusive activity of Somma-Vesuvius which is not presently detected on the flanks of the volcano or in the deep bore hole samples [Brocchini et al., 2001; Di Renzo et al., 2007].

Acknowledgements. This work was financially supported by University of Urbino (DiSPeA) research funding project-2017 entitled "Lo studio di reperti archeologici lapidei di natura vulcanica: un potente strumento di confronto reciproco per ricerche in campo vulcanologico e archeometrico" responsibility P. Santi and University of Naples Federico II (DiSTAR funds 2017 granted to $G$. Balassone). Two anonymous reviewers are acknowledged, as the paper benefited from their useful comments and suggestions.

\section{REFERENCES}

Aitchison, J. (1982). The statistical analysis of compositional data (with discussion). Journal of the Royal Statistical Society, Series B (Statistical Methodology) 44 (2), 139-177.

Aitchison, J. (1986). The Statistical Analysis of Compositional Data. Monographs on Statistics and Applied Probability. Chapman \& Hall Ltd., London (UK). (Reprinted in 2003 with additional material by The Blackburn Press). 416 p.

Aitchison, J. and M. Greenacre (2002). Biplots of compositional data. Appl. Statist., 51, Part 4, pp. 375-392.

Albore Livadie, C., E. Castaldo, N. Castaldo, B. Cesarano, D. Citro, A. D’Avella, M. Delle Donne, M.T. Pappalardo, N. Pizzano and R. Vannata (2010). Le strutture abitative e di servizio dell'insediamento dell'età del ferro di Longola (Poggiomarino, Na), Atti IX Inc. St. Preist. Protost. Etruria, Talentano, Pitigliano, September 12-14, 539-551.

Avanzinelli, R., R. Cioni, S. Conticelli, G. Giordano, R. Isaia, M. Mattei, L. Melluso and R. Sulpizio (2017). The Vesuvius and the other volcanoes of Central Italy. Geol. Field Trips, 9 (1.1), 158 pp., doi10.3301/GFT.2017.01

Balassone, G., P. Santi, A. Renzulli, G. Di Maio and V. Monetti (2013). Lithic objects from Longola protohistoric settlement (Naples): use and provenance. IX FIST Geoitalia 2013, Pisa, September 16-18, 87.

Balassone, G., P. Santi, A. Renzulli, G. Di Maio, N. Mondillo and V. Monetti (2016). Archaeometric study of volcanic lithic objects from the Longola (Poggiomarino) protohistoric site, Southern Italy: regional versus extra-regional provenance. Archaeometry, vol. 58, p. 529-548, doi: 10.1111/arcm.12195

Brocchini, D., C. Principe, D. Castradori, M.A. Laurenzi, L. Gorla (2001). Quaternary evolution of the southern sector of the Campanian Plain and earlySomma-Vesuvius activity: insighths from Trecase 1 well. Mineralogy and Petrology, 73, 67-91.

Cicirelli, C. and Albore Livadie C. (Eds.) (2012). L'abitato Protostorico di Poggiomarino, Loc. Longola. Campagne di scavo 2000 - 2004. Tomo I - II, Studi Soprint. Archeol. Pompei, 32, Ministero Beni Attività Culturali, L'Erma di Bretschneider, 480 pp.

Clarke, J.R. and K.N. Muntasser (2014). Oplontis: Villa A ("of Poppaea") at Torre Annunziata, Italy. Vol. 1, The ancient setting and modern rediscovery. New 
York: American Council of Learned Societies, 2014, http://hdl.handle.net/2027/heb.90048.0001.001.

D’Antonio, M., L. Civetta, G. Orsi, L. Pappalardo, M. Piochi, A. Caradente, S. de Vita, M.A Di Vito and R. Isaia (1999). The present state of the magmatic system of the Campi Flegrei caldera based on a reconstruction of its behavior in the past $12 \mathrm{ka}$, Journal of Volcanology and Geothermal Research, 91, 247-268.

De Bonis, A., S. Febbraro, C. Germinario, D. Giampaola, C. Grifa, V. Guarino, A. Langella A. and V. Morra (2016). Distinctive volcanic material for the production of Campana A Ware: The workshop area of Neapolis at the Duomo metro station in Naples, Italy. Geoarchaeology, 31(6), 437-466.

Di Maio, G. (2014). Oplontis: Villa A ("of Poppaea") at Torre Annunziata, Italy. Il peasaggio archeologico della costa di Oplonti, In: John R. Clarke and Nayla K. Muntasser, Eds.. Vol. 1, New York, American Council of Learned Societies, 2014, http://hdl.handle.net/2027/heb.90048.0001.001.

Di Renzo, V., M.A. Di Vito, I. Arienzo, A. Carandente, L. Civetta, M. D’Antonio and S. Tonarini (2007). Magmatic history of Somma-Vesuvius on the basis of new geochemical and isotopic data from a deep borehole (Camaldoli della Torre), Journal of Petrology, 48(4), 753-784.

Egozcue, J.J., V. Pawlowsky-Glahn, G. Mateu-Figueraz and C. Barceló-Vidal (2003). Isometric logratio transformations for compositional data analysis. Mathematical Geology 35 (3), 279-300.

Egozcue, J. J. and V. Pawlowsky-Glahn (2005). Groups of parts and their balances in compositional data analysis. Mathematical Geology 37 (7), 795-828.

Fedele, L, C. Scarpati, M. Lanphere, L. Melluso, V. Morra, A. Perrotta and G. Ricci (2008). The Breccia Museo formation, Campi Flegrei, southern Italy: geochronology, chemostratigraphy and relationship with the Campanian Ignimbrite eruption, Bulletin of Volcanology, 70, 1189-1219.

Fergola, L. and M. Pagano (1998). Oplontis - Le splendide ville romane di Torre Annunziata, Itinerario archeologico ragionato, T\&M Napoli, 10-72.

Fergola, L. (2004). Oplontis e le sue ville, Pompei (NA), Edizioni Flavius, 2004 Pompei, 128 pp.

Filzmoser, P. and K Hron (2008), Outlier detection for compositional data using robust methods. Math. Geosciences, 40, 233-248.

Guzzo, P.G. and L. Fergola (2000). Oplontis. La villa di
Poppea, F. Motta Ed., Milano, 9-30.

Izzo, F., A. Arizzi, P. Cappelletti, G. Cultrone, A. De Bonis, C. Germinario, S.F. Graziano, C. Grifa, V. Guarino, M. Mercurio, V. Morra and A. Langella (2016). The art of building in the Roman period (89 B.C. - 79 A.D.): mortars, plasters and mosaic floors from ancient Stabiae (Naples, Italy), Construction and Building Materials, 117, 129-143, doi: 10.1016/j.conbuildmat.2016.04.101.

Joron, J.L., N. Metrich, M. Rosi, R. Santacroce and A. Sbrana (1987). Chemistry and petrography, in Quaderni de "La Ricerca Scientifica» R. Sbrana Editor, 8, 105-174, CNR, Rome.

Le Bas, M.J., R.W. Le Maitre, A. Streckeisen and B. Zanettin (1986). A chemical classification of volcanic rocks based on the total alkali-silica diagram, Journal of Petrology, 27, 745-750.

Lucibello, E., G. Perrella, P. Petrosino, M. Fraldi, L. Fergola, L. Lirer and L. Nunziante (2007). La distruzione di Oplontis: relazione tra le fasi dell'eruzione del 79 d.C. e i danni rilevati nella villa di Poppea, Quaderni di Studi Pompeiani, 1. 187-200.

Malandrino, C. (1980). Oplontis, 2nd Loffredo Ed., Napoli, 58.

Martín-Fernández, J.A., J. Daunis-i-Estadella and G. Mateu-Figueras (2015). On the interpretation of differences between groups for compositional data. SORT 39 (2), 231-252.

Mojena, R. (1977) Hierarchical grouping methods and stopping rules: an evaluation. Comput J., 20:359363.

Melluso, L., R. de Gennaro, L. Fedele, L. Franciosi and V. Morra (2012). Evidence of crystallization in residual, Cl-F-rich, agpaitic, trachyphonolitic magmas and primitive Mg-rich basalt-trachyphonolite interaction in the lava domes of the Phlegrean Fields (Italy), Geological Magazine, 149, 532-550.

Muntasser, N.K. and G. Di Maio (2014). The geological landscape of Oplontis and eruption of Mount Vesuvius. In: John R. Clarke and Nayla K. Muntasser, Eds. Oplontis: Villa A ("of Poppea") at Torre Annunziata, Italy. Vol. 1, The ancient setting and modern rediscovery. New York: American Council of Learned Societies, 2014.

Pappalardo, L., L. Civetta, M. D’Antonio, A. Deino, M. Di Vito, G. Orsi, A. Carandente, S. de Vita, R.Isaia and M. Piochi (1999). Chemical and Sr-isotopical evolution of the Phlegraean magmatic system before 
the Campanian Ignimbrite and the Neapolitan Yellow Tuff eruptions, Journal of Volcanology and Geothermal Research, 91 (2-4), 141-166.

Peccerillo, A., (2005). Plio-quaternary volcanism in Italy. Springer Verlag, $365 \mathrm{pp}$.

Rosi, M. and A. Sbrana Eds. (1987). Phlegrean Fields. Quaderni de «La Ricerca Scientifica», CNR, Rome, 10, 114 pp.

Renzulli, A., F. Antonelli, P. Santi, P. Busdraghi and M. Luni (1999). Provenance determination of lava flagstones from the Roman "Via Consolare Flaminia" pavement (central Italy) using petrological investigations, Archaeometry, 41, 209-226.

Renzulli, A., P. Santi, G. Nappi, M. Luni and D. Vitali (2002a). Provenance and trade of volcanic rock millstones from Etruscan-Celtic and Roman archaeological sites in Central Italy, European Journal of Mineralogy, 14, 175-183.

Renzulli, A., P. Santi, G. Serri and M. Luni (2002b). The Euganean trachyte flagstones ("basoli") used by the Romans in the middle-Adriatic coast (Marche, central Italy): an archaeometric study, Periodico di Mineralogia, 71, Special Issue, 189-201.

Santacroce, R. and A. Sbrana (Eds.) (2003). The Vesuvius geological map, CARG Project, Servizio Geologico d'Italia, Naples.

Santacroce, R., R. Cioni, P. Marianelli, A. Sbrana, R. Sulpizio, G. Zanchetta, D.J. Donahue and J.L. Joron (2008). Age and whole rock--glass compositions of proximal pyroclastics from the major explosive eruptions of Somma-Vesuvius: A review as a tool for distal tephrostratigraphy, Journal of Volcanology and Geothermal Research, 77, 1-18.

Santi, P., F. Antonelli, A. Renzulli and P. Pensabene (2004). Leucite phonolite millstones from the Orvieto production centre: new data and insights into the Roman trade, Periodico di Mineralogia, Special Issue $32^{\circ}$ IGC, 73, 57-69.

Santi, P., A. Renzulli and M. Oddone (2010). Increasing data (INAA) on Ecuadorian obsidian artifacts: preliminary provenance and a clue for pre-Columbian eastward trade, Journal of Archaeological Science, 37, 1753-1760.

Santi, P., A. Renzulli and R. Gullo (2013). Archaeometric study of the hopper-rubber and rotary Morgantina-type volcanic millstones of the Greek and Roman periods found in the Aeolian archipelago (southern Italy), European Journal of Mineralogy, $25,39-52$.
Santi, P., A. Renzulli and M. Bell III (2015). The volcanic millstones from the archaeological site of Morgantina (Sicily): provenance and evolution of the milling techniques in the Mediterranean area, Archaeometry, 57 (5), 803-821.

Santi, P., A. Renzulli, M. Oddone, E.L. Martinez, C.A. Gonzalez Rivera (2017). Long-distance provenance for obsidian artifacts of Mesoamerica Preclassic and Early Classic periods found in the Los Naranjos Archaeological Park (Honduras), Archaeological and Anthropological Sciences, 9 (4), 555-566.

Thomas, M.L., I. van der Graaff and P. Wilkinson (2013). The Oplontis Project 2012-2013: A report of Exavations at Oplonti $\mathrm{B}, 1,2$.

Tolosana-Delgado, R. and J. McKinley (2016). Exploring the joint compositional variability of major components and trace elements in the Tellus soil geochemistry survey (Northern Ireland). Applied Geochemistry. DOI: 10.1016/j.apgeochem.2016.05.004 Ward, J.H. (1963). Hierarchical Grouping to Optimize an Objective Function. Journal of the American Statistical Association, 58, 236-244.

www.actlabs.com. Official website of the Actlabs; Activation Laboratories Ltd., Ancaster Ontario, Canada.

CORRESPONDING AUTHOR: Alberto RENZULLI,

Dipartimento di Scienze Pure e Applicate Campus Scientifico "Enrico Mattei" Univerità degli Studi di Urbino Carlo Bo Urbino, Italy email: alberto.renzulli@uniurb.it 


\section{TRACHY-PHONOLITE LAVA PEBBLES USED IN THE ANCIENT SETTLEMENT OF OPLONTIS (TORRE ANNUNZIATA, NAPLES): PETROCHEMICAL DATA SUPPORTING THE ORIGIN FROM AN OLD EFFUSIVE ACTIVITY OF THE SOMMA-VESUVIUS VOLCANO}

Alberto Renzulli ${ }^{*}, 1$, Patrizia Santi ${ }^{1}$, Giuseppina Balassone ${ }^{2}$, Giovanni di Maio ${ }^{3}$, Alberto De Bonis ${ }^{2}$, Valentino Di Donato ${ }^{2}$, Vincenzo Morra ${ }^{2}$

(1) Dipartimento di Scienze Pure e Applicate, Campus Scientifico “Enrico Mattei”, Università degli Studi di Urbino Carlo Bo, Urbino, Italia

(2) Dipartimento di Scienze della Terra, dell'Ambiente e delle Risorse, Università di Napoli Federico II, Napoli, Italia

${ }^{(3)}$ Geomed s.r.l. "Geoarcheologia e Geologia Ambientale", Scafati, Italia

Mojena index [Mojena, 1977] suggests splitting the dataset in two groups, as shown in the dendrogram (Online Supplementary Material 1: OSM1). The clustering mirrors the classification obtained with geochemical raw data analysis. In particular, the cluster 1 includes the basic-intermediate Oplontis and Longola samples, mainly phonolitic tephrites to basaltic trachyandesites whereas cluster 2 includes 0 plontis Trachy-phonolites and Longola trachytes. The MANOVA indicates that the difference between group means is significant at an alpha level of 0.05. The differences between the two clusters is highlighted in OSM2. Cluster 1 has higher values than general geometric mean for Fe $\mathrm{O}_{3}$, $\mathrm{CaO}, \mathrm{Co}-\mathrm{V}, \mathrm{TiO}_{2}$, LILE group, and lower values for $\mathrm{K}_{2} \mathrm{O}, \mathrm{Na}_{2} \mathrm{O}$, HSFE, LREE. The opposite holds for cluster 2.

The RVB (OSM1) represents, with very good approximation the multivariate dataset, as the first two axes account for about 95\% of total variability. Moreover, the first axis alone accounts for $90 \%$ of total variability. However, since the clusters represented in the biplot are significantly distinct, the RVB likely highlights the between groups rather than the within groups variance.

The closeness among most of the column points located on the positive side of axis 1 (i.e. $\mathrm{Fe}_{2} \mathrm{O}_{3}$, $\mathrm{CaO}$, $\mathrm{Co}-\mathrm{V}$, TiO ${ }_{2}$, LILE group) indicates that the log-ratios among these components are characterized by low variability. MgO is characterized by a higher relative variability. Likewise, the closeness of column points located on the negative side of axis $1\left(\mathrm{SiO}_{2}, \mathrm{Al}_{2} \mathrm{O}_{3}, \mathrm{~K}_{2} \mathrm{O}\right.$, NaO, HSFE, LRE, MHRE groups) emphasizes a reduced relative variability among these components. The variability accounted by axis 2 seems mostly related to Sr, as pointed out by its location on the negative side of axis 2 . Based on robust evaluation of atypicality at 0.95 significance level, the trachyte sample LP5, which has been included in cluster 2, can be considered as an outlier. As highlighted by its location in the RVB it is characterized by a low logratio between Sr and Mg0. The Longola sample LP4, classified as a poorly evolved trachyte in Balassone et al. [2016] appears atypical with respect to samples included in the cluster 1 . In the RVB, it occupies an intermediate position between clusters 1 and 2 . The leucite-latite Longola sample LP1 can be also considered atypical with respect to other samples of cluster 1. Among others, it is characterized by a low logratios involving $\mathrm{MgO}$ in the numerator (i.e. $\mathrm{MgO} / \mathrm{Na}_{2} \mathrm{O}, \mathrm{MgO} / \mathrm{Sr}$ ). Samples OPL7 and OPL21 appear close to the boundary outlier detection. Among others they are characterized by high log-ratios involving $\mathrm{MgO}$ and $\mathrm{CaO}$ in the numerator. 
a

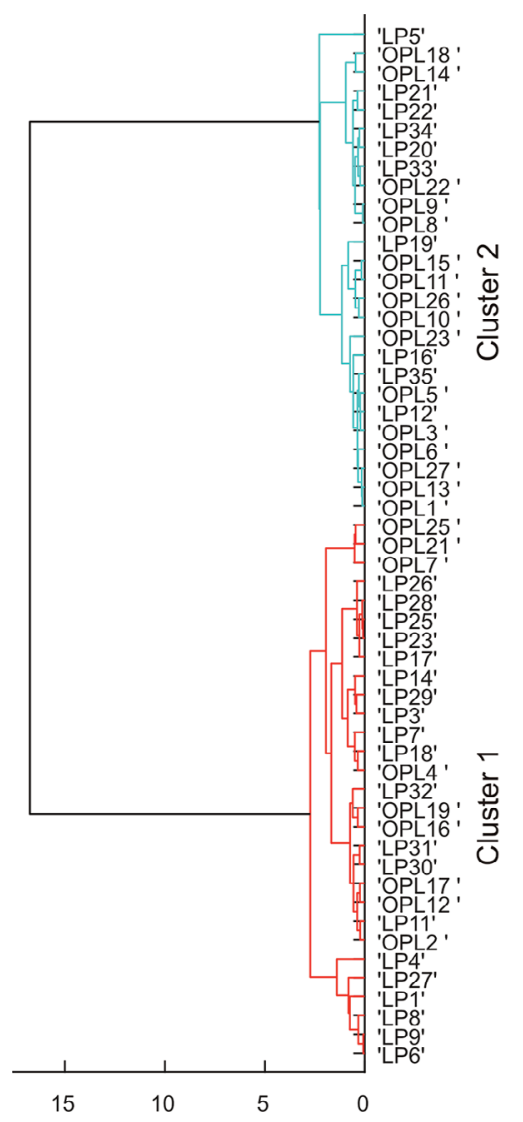

b

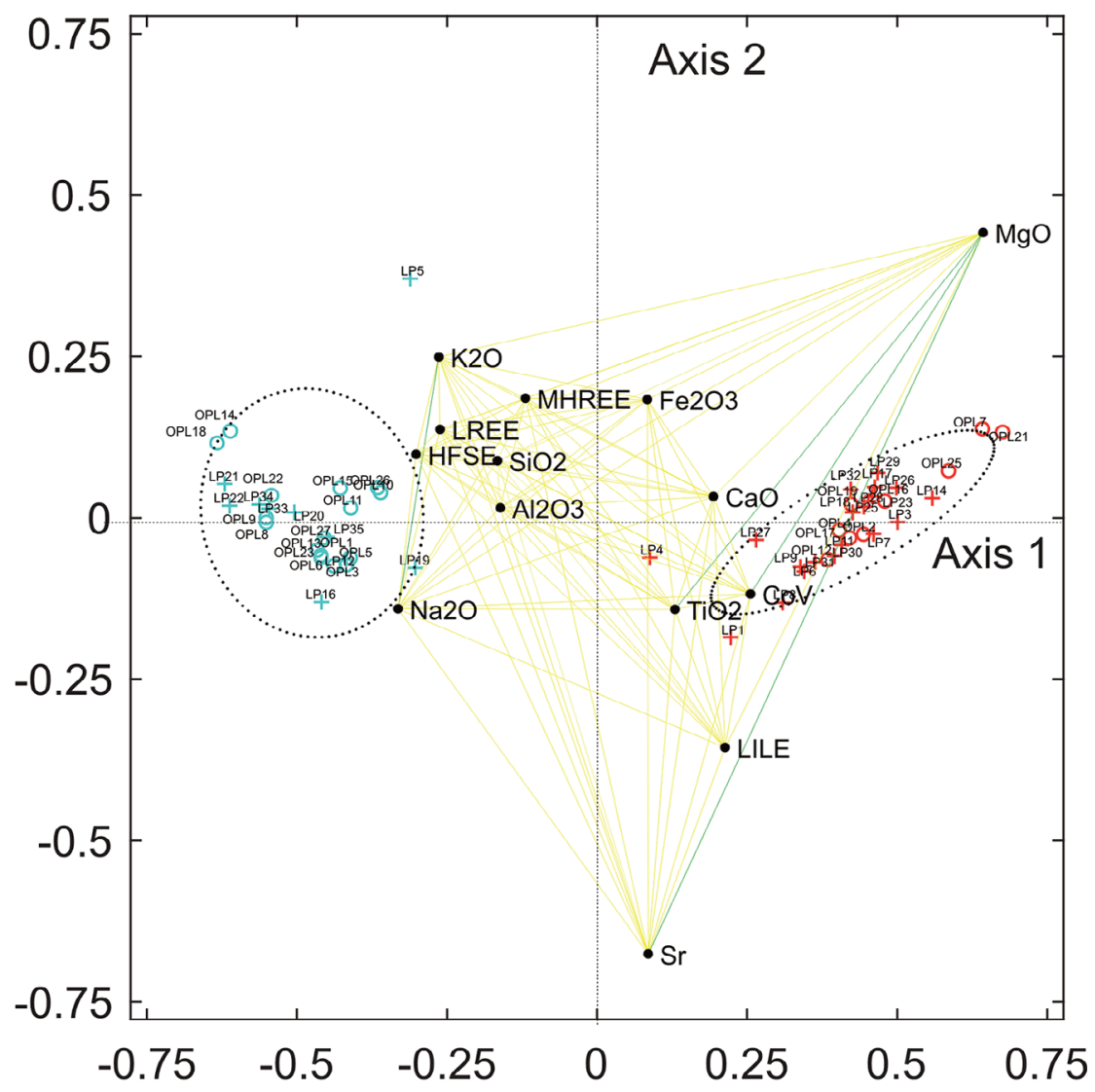

OSM1 Dendrogram (a) and Relative variation biplot (RVB) (b) of Longola and Oplontis geochemical data. Samples in the RVB are symbolised according to their provenance and grouping. Red: cluster 1; Light blue: cluster 2; circle: Oplontis; cross: Longola. Row points can be projected onto the links between two components to obtain approximations of the logratios for the individuals [Aitchison and Greenacre, 2002]. In green are highlighted links between components that in the main test were adopted to discriminate samples in Figures 7 and 8. According to their chemical behaviour in the magmatic processes, the following groups of elements are considered: LREE for La, Ce, Nd; MHREE for Sm, Gd, Tb, Dy, Ho, Er, Tm, Yb, Lu, Y; LILE for Rb, Ba; HFSE for Th, U, Zr, Hf, Nb, Ta.

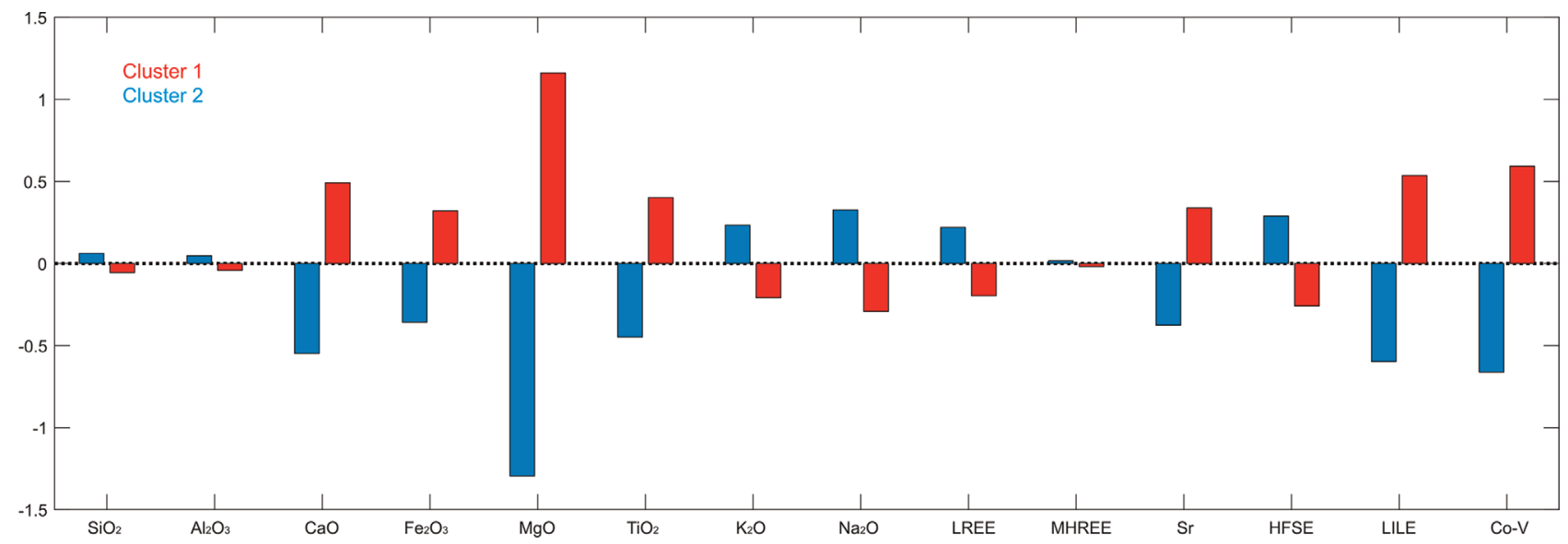

OSM2 Geometric mean barplot for Oplontis and Longola data set. The y axis is in log scale. See OSM1 for trace elements grouping. 